\title{
Insulin Receptor Signaling in Normal and Insulin-Resistant States
}

\author{
Jérémie Boucher ${ }^{1,2}$, André Kleinridders ${ }^{1,2}$, and C. Ronald Kahn ${ }^{1}$ \\ ${ }^{1}$ Section on Integrative Physiology and Metabolism, Joslin Diabetes Center and Department of Medicine, \\ Brigham and Women's Hospital and Harvard Medical School, Boston, Massachusetts 02115 \\ Correspondence: c.ronald.kahn@joslin.harvard.edu
}

In the wake of the worldwide increase in type-2 diabetes, a major focus of research is understanding the signaling pathways impacting this disease. Insulin signaling regulates glucose, lipid, and energy homeostasis, predominantly via action on liver, skeletal muscle, and adipose tissue. Precise modulation of this pathway is vital for adaption as the individual moves from the fed to the fasted state. The positive and negative modulators acting on different steps of the signaling pathway, as well as the diversity of protein isoform interaction, ensure a proper and coordinated biological response to insulin in different tissues. Whereas genetic mutations are causes of rare and severe insulin resistance, obesity can lead to insulin resistance through a variety of mechanisms. Understanding these pathways is essential for development of new drugs to treat diabetes, metabolic syndrome, and their complications.

Insulin and IGF-1 control a wide variety of biological processes by acting on two closely related tyrosine kinase receptors. Receptor activation initiates a cascade of phosphorylation events that leads to the activation of enzymes that control many aspects of metabolism and growth. Insulin/IGF-1 signaling contains many different points of regulation or critical nodes, controlled both positively and negatively, to ensure proper signal duration and intensity (see the schematic in Fig. 1). Perturbations in these signaling pathways can lead to insulin resistance. Here we review the insulin-signaling network, its critical nodes, and how these are perturbed in insulin-resistant states.

\section{INSULIN AND IGF-1 RECEPTORS}

Insulin and IGF-1 mediate their biological effects via the insulin and IGF-1 receptors (IR and IGF-1R). These highly homologous tyrosine kinase receptors are members of a family that also includes the orphan insulin receptor-related receptor (IRR), which has been suggested to play a role in testis determination (Nef et al. 2003) and act as an extracellular alkali sensor (Deyev et al. 2011). Although insulin and IGF-1 preferentially bind to their own receptors, both ligands can also bind to the alternate receptor with reduced affinity (Belfiore et al. 2009).

The IR, IGF-1R, and IRR are tetrameric proteins that consist of two extracellular $\alpha$ subunits

\footnotetext{
${ }^{2}$ These authors contributed equally to this article. Editors: Joseph Schlessinger and Mark A. Lemmon Additional Perspectives on Signaling by Receptor Tyrosine Kinases available at www.cshperspectives.org Copyright (C) 2014 Cold Spring Harbor Laboratory Press; all rights reserved; doi: 10.1101/cshperspect.a009191 Cite this article as Cold Spring Harb Perspect Biol 2014;6:a009191
} 
J. Boucher et al.

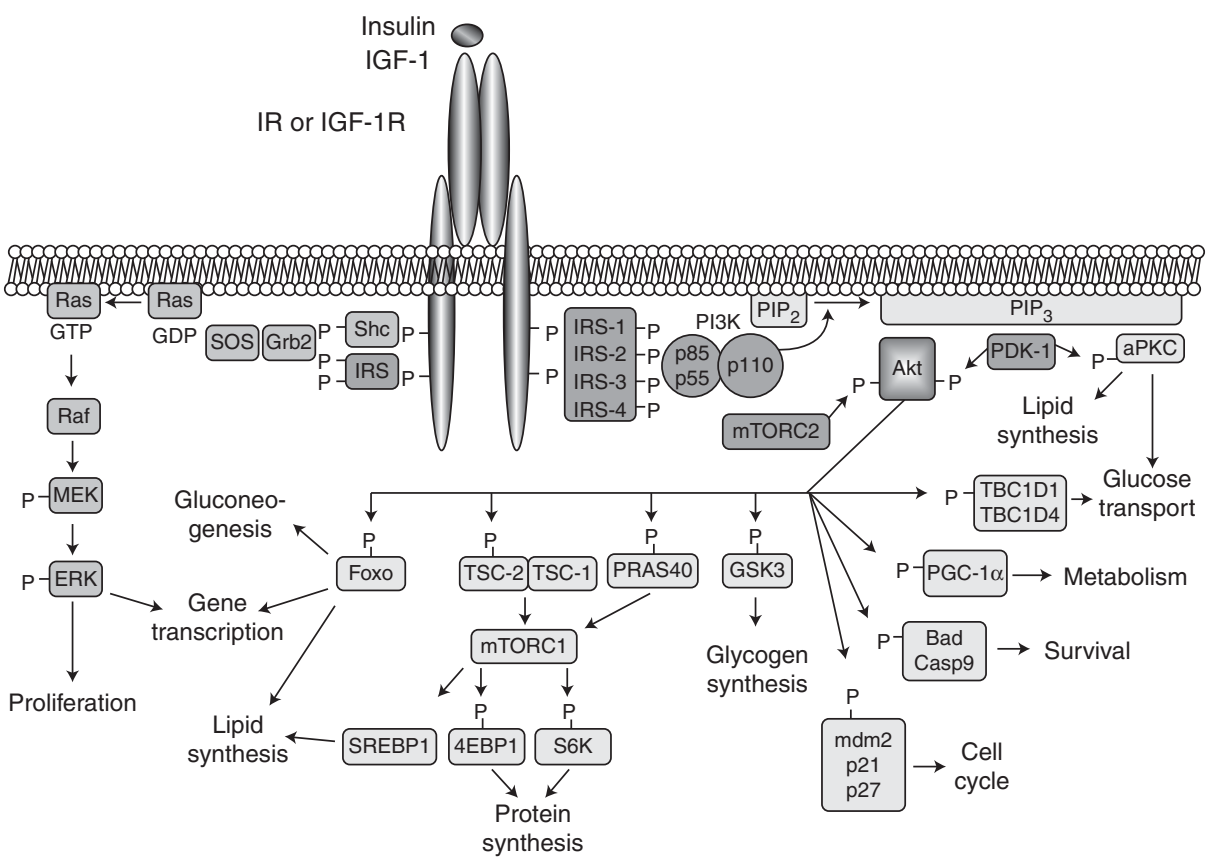

Figure 1. Insulin- and IGF-1-signaling pathways. Activation of insulin and IGF-1 receptors by their ligands initiates a cascade of phosphorylation events. A conformational change and autophosphorylation of the receptors occur at the time of ligand binding, leading to the recruitment and phosphorylation of receptor substrates such as IRS and Shc proteins. Shc activates the Ras-MAPK pathway, whereas IRS proteins mostly activate the PI3K-Akt pathway by recruiting and activating PI3K, leading to the generation of second messenger $\mathrm{PIP}_{3}$. Membrane-bound $\mathrm{PIP}_{3}$ recruits and activates PDK-1, which phosphorylates and activates Akt and atypical PKCs. Akt mediates most of insulin's metabolic effects, regulating glucose transport, lipid synthesis, gluconeogenesis, and glycogen synthesis. Akt also plays a role in the control of cell cycle and survival. The Shc-Grb2-SosRas-Raf-MAPK pathway controls cellular proliferation and gene transcription.

and two transmembrane $\beta$ subunits that are joined by disulfide bonds. Both subunits are generated from a single large precursor by proteolytic cleavage. The IR messenger RNA (mRNA) undergoes alternative splicing of exon 11 to yield two isoforms that differ by exclusion (isoform A) or inclusion (isoform B) of a 12amino-acid sequence in the carboxy-terminal part of the $\alpha$ subunit (Mosthaf et al. 1990). IR-A is predominantly expressed in fetal tissues and in the brain, has higher affinity for both insulin and IGF-2, has a higher rate of internalization than the type- $\mathrm{B}$ isoform, and tends to be up-regulated in cancer (Frasca et al. 1999), whereas IR-B expression is highest in the liver. Heterotetramers composed of an $\alpha / \beta$ dimer of IR and an $\alpha / \beta$ dimer of IGF-1R can form hybrid receptor complexes that bind preferentially
IGF-1 and IGF-2 over insulin (Benyoucef et al. 2007). Their formation appears to occur randomly in cells expressing both receptors and depends on the relative expression level of each type of receptor (Bailyes et al. 1997; Pandini et al. 1999). Insulin and IGF-1 differential effects in vivo reflect mostly the hormone concentration and relative expression level of receptors in different tissues rather than the capacity of IR and IGF-1R to convey different signaling (Boucher et al. 2010; Siddle 2012).

\section{INSULIN RECEPTOR SUBSTRATES}

At the time of ligand binding to the $\alpha$ subunits, IR and IGF-1R undergo a conformational change-inducing activation of the kinase activity in the $\beta$ subunits. This results in transphos- 
phorylation among $\beta$ subunits, further activating the kinase and allowing the recruitment of receptor substrates. The best characterized substrates are members of the insulin receptor substrate (IRS) family of proteins, simply referred to as IRS-1 through IRS-6, which act as scaffolds to organize and mediate signaling complexes (Sun et al. 1991, 1995; Lavan et al. 1997a,b; Cai et al. 2003; White 2006; Shaw 2011). IRS proteins are recruited to the membrane and the activated receptors through both pleckstrin homology (PH) and phosphotyrosine binding (PTB) domains in their amino terminus (Voliovitch et al. 1995). They are subsequently phosphorylated by the activated receptors on multiple tyrosine residues that form binding sites for intracellular molecules that contain Src-homology 2 (SH2) domains (Sun et al. 1993).

Although these substrates have similar tyrosine phosphorylation motifs, they clearly have different functions in vivo. IRS-1 knockout $(\mathrm{KO})$ mice show growth retardation and impaired insulin action, especially in muscle (Araki et al. 1994), but have normal glucose tolerance. IRS-2 KO mice display growth reduction in only selective tissues, such as certain neurons and islet cells, but also have defective insulin signaling in the liver, which when combined with the loss of $\beta$ cells results in the development of diabetes (Withers et al. 1998). At the cellular level, IRS-1 KO preadipocytes show defects in differentiation, whereas IRS-2 KO preadipocytes differentiate normally, but have impaired insulin-stimulated glucose transport (Miki et al. 2001; Tseng et al. 2005). In skeletal muscle cells, IRS-1, but not IRS-2, is required for myoblast differentiation and glucose metabolism, whereas IRS-2 is important for lipid metabolism and ERK activation (Huang et al. 2005; Bouzakri et al. 2006).

IRS- 3 and IRS- 4 show a more restricted tissue distribution pattern. In rodents, IRS-3 is most abundant in adipocytes, liver, and lung (Sciacchitano and Taylor 1997), whereas in humans, the IRS-3 gene is a pseudogene, so no protein is produced at all (Bjornholm et al. 2002). In mice, disruption of the gene for IRS3 alone does not result in abnormalities, but leads to a severe defect in adipogenesis when combined with deletion of IRS-1 (Laustsen et al. 2002). IRS-4 mRNA is present in skeletal muscle, liver, heart, brain, and kidney (Fantin et al. 1999), and IRS-4 KO mice show only very minimal growth retardation and glucose intolerance (Fantin et al. 2000). IRS-5 (also called DOK4) and IRS-6 (DOK5) have limited tissue expression (Cai et al. 2003) and are relatively poor IR substrates (Versteyhe et al. 2010).

In addition to the IRS proteins, the insulin and IGF-1 receptors can phosphorylate several other substrates (Siddle 2012). Shc proteins are tyrosine phosphorylated by IR and IGF-1R, and participate in the activation of the Ras/ERK pathway. Grb2-associated binder (GAB) proteins are also substrates for a variety of receptors, including IR and IGF-1R. GAB proteins resemble IRS proteins, but lack a protein tyrosine phosphatase (PTP) domain, and could play a role in insulin/IGF-1 signaling in cells expressing low IRS protein levels. APS (SHB2) and Cbl are IR/IGF-1R substrates that recruit other proteins, such as the Cbl-associated protein (CAP), to the insulin-signaling complex. The latter participates in the control of insulin-stimulated glucose uptake (Baumann et al. 2000). SH2B1 directly binds to insulin receptors and IRS proteins and enhances insulin sensitivity by promoting insulin receptor catalytic activity and by inhibiting tyrosine dephosphorylation of IRS proteins.

\section{PHOSPHATIDYLINOSITOL $(3,4,5)$ - TRIPHOSPHATE AND PHOSPHOINOSITIDE 3-KINASE}

The critical pathway linking IRS proteins to the metabolic actions of insulin is the PI3-kinase (PI3K) and Akt pathway. The class Ia PI3-kinases are heterodimers consisting of a regulatory and catalytic subunit, each of which occurs in several isoforms (Vadas et al. 2011). Recruitment and activation of the PI3K depends on the binding of the two $\mathrm{SH} 2$ domains in the regulatory subunits to tyrosine-phosphorylated IRS proteins (Myers et al. 1992; Shaw 2011). This results in activation of the catalytic subunit, which rapidly phosphorylates phosphatidylinositol 4,5-bisphosphate $\left(\mathrm{PIP}_{2}\right)$ to generate 
J. Boucher et al.

the lipid second messenger phosphatidylinositol $(3,4,5)$-triphosphate $\left(\mathrm{PIP}_{3}\right)$. The latter recruits Akt to the plasma membrane, where it is activated by phosphorylation and induces downstream signaling.

The different isoforms of the regulatory subunit of PI3K are encoded by three distinct genes. Pik $3 r 1$ encodes $65 \%-75 \%$ of all regulatory subunits, mostly in the form of p85 $\alpha$, but also the splice variants $\mathrm{p} 55 \alpha$ and $\mathrm{p} 50 \alpha$. Pik3r2 encodes p $85 \beta$ and accounts for $\sim 20 \%$ of the regulatory subunits. Pik3r3 encodes p55 $\gamma$, which is similar in structure to $\mathrm{p} 55 \alpha$, but expressed at low levels in most tissues.

The three different catalytic subunitsp $110 \alpha, \beta$, and $\delta$ - are derived from three different genes. Binding of a regulatory to a catalytic subunit increases the catalytic subunit stability and maintains it in an inhibited state. This is relieved by binding of the regulatory subunit to specific phosphotyrosine motifs in IRS proteins, resulting in its activation (Yu et al. 1998; Burke et al. 2011; Zhang et al. 2011). Liver-specific ablation of $\mathrm{p} 110 \alpha$, and to a lesser extent p110 $\beta$, in mice results in glucose intolerance and insulin resistance (Jia et al. 2008; Sopasakis et al. 2010). Surprisingly, knockouts of the regulatory subunits of PI3K, including a heterozygous deletion of $\mathrm{p} 85 \alpha, \mathrm{p} 85 \beta \mathrm{KO}$, or $\mathrm{p} 50 \alpha / \mathrm{p} 55 \alpha$ double $\mathrm{KO}$, all display increased insulin sensitivity (Terauchi et al. 1999; Ueki et al. 2002). Different mechanisms by which reducing concentration of regulatory subunits can increase insulin action have been identified. Regulatory subunits typically are in excess concentration to catalytic subunits and thus compete with the enzymatically competent p85/p110 heterodimer for binding to IRS proteins. The $\mathrm{p} 85 \alpha$ monomer has also been linked to regulation of the phosphatase and tensin homolog (PTEN) (Taniguchi et al. 2010). More recently, p $85 \alpha$ has been shown to bind to the transcription factor XBP-1 and to modify the unfolded protein response, which contributes to insulin resistance (Park et al. 2010; Winnay et al. 2010).

In addition to PI3K, IRS proteins recruit other proteins potentially contributing to insulin and IGF-1 action. Proteomics analysis of the phosphotyrosine interactome of IRS-1 and
IRS-2 indicates that most interacting proteins bind to both substrates, such as adaptor proteins Grb2 or Crk, or tyrosine phosphatase SHP2. However, other interaction partners seem to bind exclusively to IRS-1 (Csk) or IRS-2 (Shc, DOCK-6, and DOCK-7) (Hanke and Mann 2009).

\section{ACTIVATION OF DOWNSTREAM KINASES}

Most of the physiological effects of PI3K-generated $\mathrm{PIP}_{3}$ are mediated by a subset of AGC protein kinase family members, which include isoforms of Akt/protein kinase B (PKB), p70 ribosomal S6 kinase (S6K), serum- and glucocorticoid-induced protein kinase (SGK), as well as several isoforms of protein kinase C (PKC), particularly the atypical PKCs. AGC kinase family members share similar structure and mechanisms of activation via phosphorylation of two serine and threonine residues (Pearce et al. 2010). PDK-1 (3-phosphoinositide-dependent protein kinase 1 ) is the major upstream kinase responsible for the phosphorylation and activation of the AGC kinase members regulated by PI3K (Bayascas 2010). PDK-1 contains a $\mathrm{PH}$ domain that binds to membrane-bound $\mathrm{PIP}_{3}$, triggering PDK-1 activation. PDK-1 phosphorylates and activates AGC protein kinases at serine/threonine residues, such as Thr-308 for Akt (Alessi et al. 1997). However, Akt phosphorylation at Ser-473 is required for full activation, and this is accomplished by the mammalian target of rapamycin complex 2 (mTORC2) (Sarbassov et al. 2005; Oh and Jacinto 2011). DNA-dependent protein kinase (DNA PK) has also been described to phosphorylate and activate Akt in response to DNA damage (Bozulic et al. 2008), and is involved in insulin regulation of metabolic genes such as fatty acid synthase (Wong et al. 2009).

The Akt/PKB family of proteins consists of three different isoforms of serine/threonine protein kinases encoded by different genes (Schultze et al. 2011). All isoforms possess a $\mathrm{PH}$ domain, allowing interaction with $\mathrm{PIP}_{3}$ and recruitment to the plasma membrane. Akt2 is most abundant in insulin-sensitive tissues and seems to play a predominant role in 
mediating insulin action on metabolism. Thus, Akt2 $\mathrm{KO}$ mice are insulin resistant and develop diabetes (Cho et al. 2001), whereas Akt1 and Akt3 KO mice do not.

\section{ACTIONS OF INSULIN DOWNSTREAM FROM AKT}

Activation of Akt by PDK-1 and mTORC 2 allows the phosphorylation and activation of many downstream targets. Akt phosphorylates tuberous sclerosis complex protein 2 (TSC-2), inducing the degradation of the tumor suppressor complex that consists of TSC-2 and TSC-1, which activates the mTORC1 complex. Akt-induced activation of mTORC1 can also be achieved by phosphorylation of proline-rich Akt substrate $40 \mathrm{KDa}$ (PRAS40), an inhibitor of mTORC1, thereby relieving the inhibition. The mTORC1 complex then phosphorylates and inhibits 4Ebinding protein 1 (4E-BP1), activates ribosomal protein S6 kinases S6K1 and S6K2 and SREBP1, and leads to the regulation of a network of genes controlling metabolism, protein synthesis, and cell growth (Duvel et al. 2010).

Transcription factors of the Forkhead box O (Foxo) family control the expression of lipogenic and gluconeogenic genes. Akt phosphorylates Foxos at several sites which provides docking sites for binding proteins of the 14-33 family. This interaction leads to the exclusion of Foxo from the nucleus, thus blocking its transcriptional activity (Tzivion et al. 2011). Interestingly, although mice lacking Akt1 and Akt2 show severe hepatic insulin resistance and high levels of hepatic glucose production, these defects are normalized when Foxol is concomitantly ablated in the liver. This indicates that an additional pathway exists in the control of hepatic glucose metabolism beyond the Akt/Foxol axis, which allows for insulinmediated regulation of hepatic glucose production (Lu et al. 2012).

There are multiple other substrates of Akt involved in insulin action. The GTPase-activating protein Akt substrate of $160 \mathrm{kDa}$ (AS160), also called TBC1D4, and its homolog TBC1D1, are phosphorylated by Akt and are involved in insulin- and contraction-mediated glucose uptake (Sano et al. 2003; Sakamoto and Holman 2008; Taylor et al. 2008; An et al. 2010). Akt also phosphorylates and inactivates glycogen synthase kinase 3, resulting in glycogen synthase activation and glycogen accumulation in liver (Kim et al. 2004b). Akt-dependent phosphorylation of PGC- $1 \alpha$ impairs the ability of PGC- $1 \alpha$ to promote gluconeogenesis and fatty acid oxidation ( $\mathrm{Li}$ et al. 2007). Phosphorylation of phosphodiesterase 3B (PDE3B) by Akt results in its activation and in a decrease in cyclic AMP levels (Kitamura et al. 1999), which plays important roles in the effect of insulin to inhibit lipolysis in adipocytes and insulin secretion in $\beta$ cells (Degerman et al. 2011).

\section{OTHER ACTIONS OF INSULIN DOWNSTREAM FROM PI3K}

Akt plays a central role in mediating many other insulin actions by regulating the expression and activity of a wide range of proteins, including enzymes, transcription factors, cell cycle regulating proteins, or apoptosis and survival proteins (Manning and Cantley 2007). Murine double minute $2(\mathrm{Mdm} 2)$ is phosphorylated by Akt, which inhibits p53-mediated apoptosis and contributes to tumorigenesis (Cheng et al. 2010). Akt phosphorylates cell cycle inhibitors p21Cip1/WAF1 and p27Kip1, resulting in cytoplasmic localization, cell growth, and inhibition of apoptosis (Zhou et al. 2001; Motti et al. 2004). Akt also phosphorylates and inhibits Bax, Bad, and caspase-9, which promotes cell survival (Datta et al. 1997; Cardone et al. 1998; Yamaguchi and Wang 2001; Gardai et al. 2004). Akt can phosphorylate and activate IkB kinase (IKK), leading to NF- $\mathrm{BB}$ activation (Bai et al. 2009). Akt phosphorylates and activates endothelial nitric oxide synthase (eNOS), which catalyzes the production of the vasodilator and anti-inflammatory molecule nitric oxide (NO), providing a potential link between insulin resistance and cardiovascular disease (Dimmeler et al. 1999; Fulton et al. 1999; Yu et al. 2011a). Although less well studied in insulin action, the serum- and glucocorticoid-induced protein family of kinases (SGK) are highly homologous to Akt, are also activated by dual phosphoryla- 
J. Boucher et al.

tion by PDK-1 and mTORC2 in a PI3K dependent manner, and have many downstream substrates in common with Akt (Bruhn et al. 2010).

\section{PROTEIN KINASES C}

PKC isoforms are both mediators and modifiers of insulin's metabolic action. Of the three major classes of PKC, the atypical PKCs (aPKCs), PKC$\zeta$ and $\mathrm{PKC}-\lambda / \iota$, are activated via phosphorylation by PDK-1. aPKCs play an important role in insulin-stimulated glucose transport and regulation of lipid synthesis, and their expression and/or activation is decreased in muscle from obese and diabetic humans (Farese and Sajan 2010). Both PKC- $\lambda$ and PKC- $\zeta$ have been shown to function interchangeably in mediating insulin-stimulated glucose transport (Sajan et al. 2006). Muscle-specific deletion of PKC- $\lambda$ in mice leads to impairment in insulin-induced glucose uptake and insulin resistance (Farese et al. 2007). Mice with liver-specific deletion of $\mathrm{PKC}-\lambda$ display decreased insulin-induced expression of SREBP1c and triglyceride content in the liver, resulting in increased insulin sensitivity in these mice (Matsumoto et al. 2003).

\section{THE GRB2-SOS-RAS-MAPK PATHWAY}

A second essential branch of the insulin/IGF-1signaling pathway is the Grb2-SOS-Ras-MAPK pathway, which is activated independently of PI3K/Akt. Activated receptors and IRS proteins both possess docking sites for adaptor molecules that contain SH2 domains such as Grb2 and Shc. The carboxy-terminal SH3 domain of Grb2 binds to proteins such as Gab-1, whereas the amino-terminal SH3 domain binds to proline-rich regions of proteins such as son-ofsevenless (SOS). SOS is a guanine nucleotide exchange factor (GEF) for Ras, catalyzing the switch of membrane-bound Ras from an inactive, GDP-bound form (Ras-GDP) to an active, GTP-bound form (Ras-GTP). Ras-GTP then interacts with and stimulates downstream effectors, such as the Ser/Thr kinase Raf, which stimulates its downstream target MEK1 and 2 that phosphorylate and activate the MAP kinases ERK1 and 2. Stimulated ERK1/2 play a direct role in cell proliferation or differentiation, regulating gene expression or extra-nuclear events, such as cytoskeletal reorganization, through phosphorylation and activation of targets in the cytosol and nucleus.

\section{NEGATIVE REGULATORS OF INSULIN SIGNALING}

Insulin and IGF-1 signaling are tightly controlled because uncontrolled activity of the downstream pathways could lead to severe perturbations in metabolism and tumorigenesis. Intensity and duration of the signal play an important role in determining the specificity of the response to their pleiotropic effects. Therefore, the ability to turn off the insulin signal in a rapid manner at different levels is critical (Fig. 2). On the other hand, some of these inhibitory mechanisms can be altered in pathophysiological conditions and participate in the development of insulin resistance.

\section{Phosphoprotein Phosphatases as Negative Regulators of Insulin Action}

Both cytoplasmic protein tyrosine phosphatases, such as PTP1B, and transmembrane phosphatases, such as LAR, have been shown to dephosphorylate the tyrosine residues on activated IR and IGF-1R, as well as IRS proteins, thereby reducing their activity (Goldstein et al. 1998). Although the role of LAR in the control of insulin signaling in vivo remains controversial, PTP1B is an essential component of insulin action. PTP1B KO mice show enhanced insulin sensitivity, increased IR phosphorylation in muscle and liver, and are also resistant to highfat-diet-induced obesity and associated insulin resistance (Elchebly et al. 1999; Klaman et al. 2000).

The serine/threonine phosphatase protein phosphatase 1 (PP1) has been implicated in the regulation of several rate-limiting enzymes in both glucose and lipid metabolism, including glycogen synthase, hormone-sensitive lipase, or acetyl CoA carboxylase (Brady and Saltiel 2001). Protein phosphatase 2A (PP2A), which accounts for $\sim 80 \%$ of serine/threonine phos- 


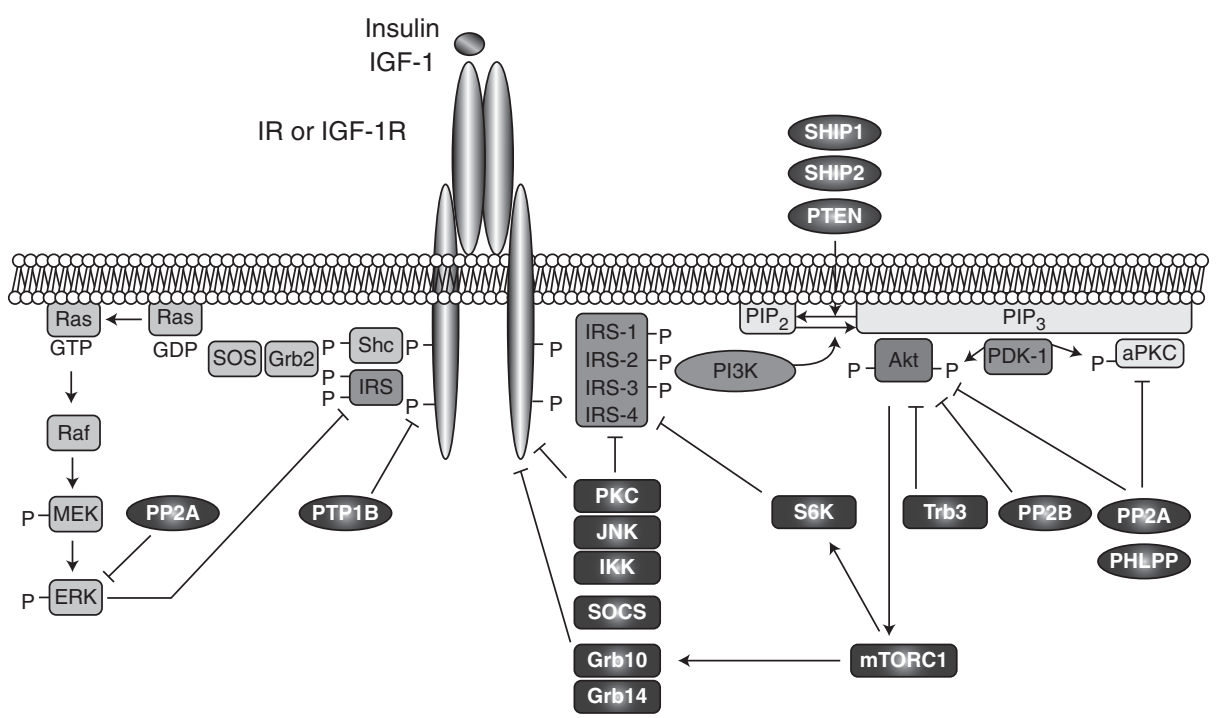

Figure 2. Negative modulators of insulin and IGF-1 signaling. Intensity and duration of insulin and IGF-1 signaling play an important role in determining the specificity and the nature of the response to these hormones. Signaling is attenuated by action of several phosphatases, which dephosphorylate the receptors, IRS proteins,

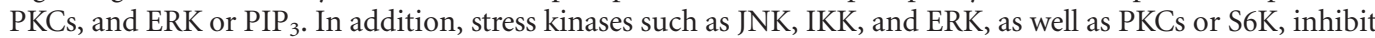
insulin/IGF-1 signaling by inducing inhibitory serine/threonine phosphorylation of IR/IGFR and IRS proteins. Trb3 inhibits Akt, and adaptor proteins such as SOCS and Grb bind to the receptors and IRS proteins and inhibit signaling by competition.

phatase activity in cells, also regulates the activities of many protein kinases involved in insulin action, including Akt, PKC, S6K, ERK, cyclindependent kinases, and IKK (Millward et al. 1999). Several studies indicate that PP2A is hyperactivated in diabetic states (Kowluru and Matti 2012).

Other serine/threonine phosphatases have been implicated in insulin action. Protein phosphatases 2B (PP2B), also known as calcineurin, has been shown to dephosphorylate Akt ( $\mathrm{Ni}$ et al. 2007). Two novel members of the PP2C family involved in regulation of insulin action are the $\mathrm{PH}$ domain leucine-rich repeat protein phosphatases PHLPP-1 and -2, which dephosphorylate both Akt and PKCs (Brognard and Newton 2008). Overexpression of PHLPP1 in cells impairs Akt and glycogen synthase kinase 3 activity, resulting in decreased glycogen synthesis and glucose transport (Andreozzi et al. 2011). Elevated levels of PHLPP1 have been found in adipose tissue and skeletal muscle of obese and/or diabetic patients and correlate with decreased Akt2 phosphorylation (Cozzone et al. 2008; Andreozzi et al. 2011).

Lipid Phosphatases as Negative Regulators of Insulin Action

Lipid phosphatases can regulate insulin signaling by modulating $\mathrm{PIP}_{3}$ levels. PTEN dephosphorylates $\mathrm{PIP}_{3}$, thus antagonizing $\mathrm{PI} 3 \mathrm{~K}$ signaling in cells (Cantley and Neel 1999; Carracedo and Pandolfi 2008). Muscle, adipose tissue, or liver-specific deletion of PTEN in mice increases insulin sensitivity (Stiles et al. 2004; Kurlawalla-Martinez et al. 2005; Wijesekara et al. 2005), and mice with whole-body PTEN haploinsufficiency show improved glucose tolerance and increased insulin sensitivity (Wong et al. 2007). Interestingly, the p $85 \alpha$ regulatory subunit of PI3K has recently been shown to bind directly to and enhance PTEN activity, creating a unique interface between the generation and degradation of $\mathrm{PIP}_{3}$ (Taniguchi et al. 2006b; Chagpar et al. 2010). 
J. Boucher et al.

SH2 domain-containing inositol 5-phosphatases (SHIP) 1 and 2 also dephosphorylate $\mathrm{PIP}_{3}$. SHIP1 expression is restricted to hematopoietic cells, whereas SHIP2 is ubiquitously expressed and plays a role in insulin signaling (Suwa et al. 2010). SHIP2 deficiency in mice results in hypoglycemia, enhanced insulin-induced Akt activation, and resistance to highfat-diet-induced obesity, indicating that SHIP2 is a key regulator of glucose and energy homeostasis in vivo (Clement et al. 2001; Sleeman et al. 2005). Conversely, SHIP2-overexpressing mice show reduced insulin-induced Akt activation in the liver, fat, and skeletal muscle (Kagawa et al. 2008).

Other Negative Modulators (Grb, SOCS, Trb3, IP7)

Grb10 and Grb14 are cytoplasmic adaptor proteins that decrease IR and to a lesser extent IGF$1 \mathrm{R}$ activity, and prevent access of substrates to the activated receptors (Holt and Siddle 2005). Deletion of the Grb10 gene in mice leads to increased growth, enhanced insulin signaling, and increased glucose tolerance (Smith et al. 2007; Wang et al. 2007). Grb10 overexpression, on the other hand, results in impaired growth, glucose intolerance, and insulin resistance (Shiura et al. 2005). Grb14 expression is increased in adipose tissue of insulin-resistant animal models and type- 2 diabetic patients (Cariou et al. 2004), and Grb14 KO mice display increased glucose tolerance and insulin sensitivity, consistent with an inhibitory role of Grb14 on insulin signaling (Cooney et al. 2004). Grb10 and Grb14 share similar mechanisms as insulin signaling is not further increased in mice with deletion of both proteins (Holt et al. 2009).

Proteins of the suppressor of cytokine signaling (SOCS) family are adaptor proteins that act as negative regulators of cytokine and growth factor signaling. In addition, SOCS proteins, in particular SOCS1 and SOCS3, negatively regulate insulin signaling and thus link cytokine signaling to insulin resistance. Their expression is increased in obesity, and they induce insulin resistance via either inhibition of the tyrosine kinase activity of the IR, competi- tion for binding of the IRS proteins to the receptor, or targeting the IRS proteins to degradation (Emanuelli et al. 2000, 2001; Rui et al. 2002; Ueki et al. 2004a,b; Sachithanandan et al. 2010).

Tribbles homolog 3 (Trb3) is a member of the family of pseudokinases that is thought to function as adaptor proteins. Trb3 expression is induced in liver in fasting and diabetes, and disrupts insulin signaling by binding to Akt and blocking its activation. Trb3 knockdown in mice improves glucose tolerance ( $\mathrm{Du}$ et al. 2003; Koo et al. 2004). In cultured cells, insulinstimulated S6K activation is decreased when Trb3 is overexpressed, and increased when Trb3 levels are reduced (Matsushima et al. 2006). Trb3 action in adipose tissue seems to be independent of Akt. Thus, whereas insulin promotes lipogenesis, Trb3 stimulates lipolysis by triggering the ubiquitination and degradation of acetyl-CoA carboxylase. Transgenic mice overexpressing Trb3 in adipose tissue are protected from diet-induced obesity because of enhanced fatty acid oxidation and display increased insulin sensitivity (Qi et al. 2006).

A novel negative regulator of insulin signaling is the inositol phosphate IP7. It was recently shown that insulin and IGF-1 increase IP7 levels, which in turn inhibits Akt translocation to the plasma membrane and subsequent activation, creating a potential feedback mechanism that attenuates insulin signaling (Chakraborty et al. 2010). Deletion of the enzyme that catalyzes IP7 formation in mice causes increased insulin responsiveness. Further studies will be needed to elucidate the contribution of this pathway in normal or pathological conditions.

Regulation by Inhibitory Serine and Threonine Phosphorylation

Tyrosine phosphorylation is essential for IR/ IGF-1R and IRS activation. On the other hand, serine and threonine phosphorylation of the receptors or IRS proteins is primarily involved in turning the insulin signal down (Fig. 3). Increased inhibitory Ser/Thr phosphorylation of IR and especially IRS-1 and - 2 occurs in response to cytokines, fatty acids, hyperglycemia, 


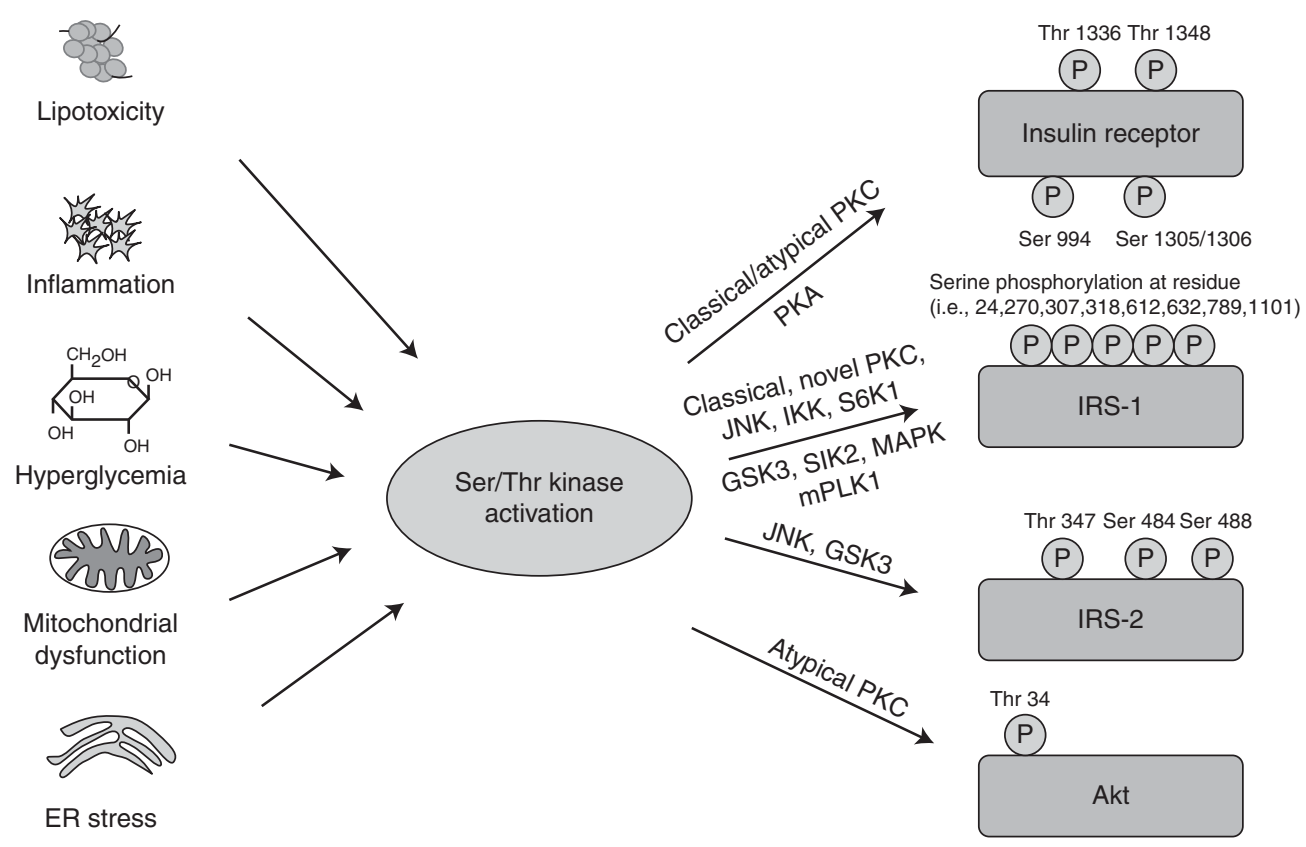

Figure 3. Activation of Ser/Thr kinases causes inhibitory phosphorylation on insulin-signaling molecules. Lipotoxicity, inflammation, hyperglycemia, and subsequently oxidative stress, as well as mitochondrial dysfunction and ER stress, all converge on activation of Ser/Thr kinases, inducing inhibitory Ser/Thr phosphorylation of IR, IRS proteins, and Akt on multiple residues, causing insulin resistance.

mitochondrial dysfunction, and ER stress, and insulin itself via activation of multiple kinases, predominantly by c-Jun amino-terminal kinase (JNK), IKK, conventional and novel PKCs, but also mTORC1/S6K and MAPK (De Fea and Roth 1997a; Aguirre et al. 2000; Gao et al. 2002; Gual et al. 2003; Li et al. 2004; Zhang et al. 2008a; Boura-Halfon and Zick 2009). Increased IR serine phosphorylation associated with decreased tyrosine kinase activity has been observed in insulin-resistant states, both in rodents and in humans (Karasik et al. 1990; Dunaif et al. 1995; Zhou et al. 1999; Shao et al. 2000). An increase in cAMP concentration also induces inhibitory serine phosphorylation of IR in a PKA-dependent manner (Stadtmauer and Rosen 1986; Roth and Beaudoin 1987).

Although inhibitory IRS-1 serine phosphorylation occurs at many different sites (BouraHalfon and Zick 2009), the best studied of these modifications occurs at Ser-307 (Aguirre et al. 2002). IRS-1 Ser-307 phosphorylation is increased in obese and diabetic mice (Hirosumi et al. 2002; Um et al. 2004). Although this is widely believed to contribute to insulin resistance by inhibiting insulin receptor kinase activity, recent studies have made this association less clear. Thus, insulin itself can stimulate phosphorylation of IRS-1 on Ser-307 in humans (Yi et al. 2007), and mice with a knockin of IRS-1 Ser307Ala mutant developed more severe insulin resistance than control mice when fed a high-fat diet, indicating that Ser-307 is required to maintain normal insulin signaling (Copps et al. 2010). Thus, increased IRS-1 Ser307 phosphorylation observed in insulin-resistance states may be associated with, but not cause, insulin resistance.

Lipids, through their metabolic product diacylglycerols, can activate classical $(\alpha, \beta, \gamma)$ and novel PKC members $(\delta, \theta, \varepsilon)$ and impair insulin signaling by inducing multiple serine phosphorylation of IRS proteins and IR specifically at Thr-1336, Thr-1348, and Ser-1305/1306 (Bollag et al. 1986; Karasik et al. 1990; Lewis et al. 1990; Chin et al. 1993; De Fea and Roth 
J. Boucher et al.

1997b; Turban and Hajduch 2011). Thus, deletion of any member of the novel PKC family prevents the development of insulin resistance in skeletal muscle and liver by decreasing IRS-1 Ser-307 phosphorylation (Kim et al. 2004a; Samuel et al. 2007; Mack et al. 2008; Bezy et al. 2011). Atypical PKC- $\zeta$ also inhibits insulin signaling by inducing serine phosphorylation of IRS-1 (Ravichandran et al. 2001) and Thr34 phosphorylation of Akt, thereby inhibiting its recruitment to the plasma membrane (Powell et al. 2003, 2004).

Another component of the negative feedback loops in insulin signaling is mTORC1. Activation of mTOR and S6K is not only downstream from insulin signaling, but also inhibits it by increasing serine phosphorylation and reducing IRS tyrosine phosphorylation. This is illustrated by the phenotype of S6K null mice, which are lean and display enhanced insulin sensitivity (Um et al. 2004). In addition, IRS-1 is hyperphosphorylated and degraded in TSC-2 KO fibroblasts, which show constitutive S6K activation (Harrington et al. 2004; Shah et al. 2004). mTORC1 also mediates phosphorylation and stabilization of Grb10, leading to feedback inhibition of insulin signaling (Hsu et al. 2011; Yu et al. 2011b).

\section{MECHANISMS OF INSULIN RESISTANCE}

A central feature of type- 2 diabetes is insulin resistance, a condition in which cells cannot respond properly to insulin. This occurs primarily at the level of so-called insulin-sensitive tissues, such as liver, muscle, and fat, and can be caused by multiple mechanisms (Fig. 3 and Table 1).

\section{Genetic Causes of Insulin Resistance}

\section{Insulin Receptor}

Mutations in the insulin receptor gene have been identified in several rare forms of severe insulin resistance, including leprechaunism, Rabson-Mendenhall syndrome, or the type-A syndrome of insulin resistance. These patients often require a hundredfold or more insulin than a typical diabetic patient (Kahn et al. 1976; Cochran et al. 2005). Most of these patients have nonsense or missense mutations in the extracellular ligand-binding domain or intracellular tyrosine kinase domain of the receptor, which leads to severely reduced insulin binding, altered kinetics of insulin binding, or reduced tyrosine kinase activity, but some also have presumed promoter defects leading to reduced receptor mRNA expression (Taylor et al. 1991; Haruta et al. 1995). Insulin receptor mutations have not been observed in patients with routine type-2 diabetes (T2D).

\section{Insulin Receptor Substrate Proteins}

The G972R polymorphism of IRS-1 is observed with higher frequency in patients with T2D and leads to decreased insulin signaling, mostly decreasing PI3K activity (Almind et al. 1996; Hribal et al. 2008). Although this finding has not been confirmed in all large-scale population analyses (Florez et al. 2004; van Dam et al. 2004), recent studies have continued to show an association between a single-nucleotide polymorphism (SNP) in IRS-1 and T2D (Burguete-Garcia et al. 2010; Martinez-Gomez et al. 2011). AT608R missense mutation in IRS1 resulting in decreased insulin signaling has been reported in a patient with T2D, but appears to be very rare (Esposito et al. 2003). Numerous polymorphisms have been identified in the human IRS-2 gene, but a clear association between these polymorphisms and T2D has not been found (Bernal et al. 1998).

\section{Phosphoinositide 3-Kinase}

An M326I polymorphism in the p $85 \alpha$ regulatory subunit of the PI3K was identified in Pima Indian women and is associated with decreased prevalence for T2D (Baier et al. 1998). However, this M326I mutation only has modest effects on insulin signaling in vitro by decreasing $\mathrm{p} 85 \alpha$ binding to IRS- 1 and increasing p $85 \alpha$ degradation (Almind et al. 2002). Another polymorphism in $p 85 \alpha$ (SNP42) is associated with fasting hyperglycemia, but its molecular mechanism so far remains elusive (Barroso et al. 2003). 
Insulin Receptor Signaling

Table 1. Molecular mechanisms of insulin resistance

\begin{tabular}{|c|c|c|c|}
\hline Cause & Mechanism & Effect & References \\
\hline $\begin{array}{l}\text { Lipotoxicity } \\
\text { Inflammation } \\
\text { Hyperglycemia } \\
\text { Mitochondrial } \\
\text { dysfunction } \\
\text { ER stress }\end{array}$ & $\begin{array}{l}\text { Activation of Ser/ } \\
\text { Thr kinases }\end{array}$ & $\begin{array}{l}\text { Inhibitory phosphorylation } \\
\text { of insulin-signaling } \\
\text { molecules }\end{array}$ & $\begin{array}{l}\text { Bollag et al. 1986; Karasik et al. 1990; } \\
\text { Lewis et al. 1990; Chin et al. 1993; } \\
\text { Powell et al. 2003; Boura-Halfon } \\
\text { and Zick, } 2009\end{array}$ \\
\hline \multirow[t]{2}{*}{ Genetic mutations } & $\begin{array}{l}\text { Point mutations in } \\
\text { IR and insulin- } \\
\text { signaling } \\
\text { molecules }\end{array}$ & $\begin{array}{l}\text { Increased protein turnover } \\
\text { Reduced expression and } \\
\text { ligand affinity } \\
\text { Decreased signaling } \\
\text { capacities }\end{array}$ & $\begin{array}{l}\text { Kahn et al. 1976; Taylor et al. 1991; } \\
\text { Haruta et al. 1995; Almind et al. } \\
\text { 1996; George et al. 2004; Prudente } \\
\text { et al. 2005; Hribal et al. 2008; Dash } \\
\text { et al. 2009; Prudente et al. } 2009\end{array}$ \\
\hline & $\begin{array}{l}\text { SNP causing } \\
\text { increased gene } \\
\text { expression }\end{array}$ & $\begin{array}{l}\text { Increased PTEN action } \\
\text { leading to reduced } \mathrm{PIP}_{3} \\
\text { levels }\end{array}$ & Ishihara et al. 2003 \\
\hline Lipotoxicity & $\begin{array}{l}\text { Hyperactivation of } \\
\text { protein } \\
\text { phosphatase } \\
\text { PP2A }\end{array}$ & $\begin{array}{l}\text { Reduced phosphorylation } \\
\text { of IR and insulin- } \\
\text { signaling molecules }\end{array}$ & Kowluru and Matti 2012 \\
\hline \multirow[t]{2}{*}{ Inflammation } & $\begin{array}{l}\text { Cytokine-induced } \\
\text { SOCS3 activation }\end{array}$ & $\begin{array}{l}\text { Inhibition or IR tyrosine } \\
\text { kinase activity } \\
\text { Competition for IRS } \\
\text { binding to IR } \\
\text { Increased IRS degradation }\end{array}$ & $\begin{array}{l}\text { Emanuelli et al. 2000, 2001; Rui et al. } \\
\text { 2002; Ueki et al. 2004a,b; Steppan } \\
\text { et al. } 2005\end{array}$ \\
\hline & $\begin{array}{l}\text { Cytokine-induced } \\
\text { reduction in gene } \\
\text { expression }\end{array}$ & $\begin{array}{l}\text { Decreased expression of } \\
\text { insulin-signaling } \\
\text { molecules }\end{array}$ & Rotter et al. 2003; Jager et al. 2007 \\
\hline \multirow[t]{2}{*}{ Hyperglycemia } & $\begin{array}{l}\text { Glycation of insulin- } \\
\text { signaling } \\
\text { molecules }\end{array}$ & $\begin{array}{l}\text { Reduced affinity for IR } \\
\text { Decreased DNA-binding } \\
\text { capacities of transcription } \\
\text { factors }\end{array}$ & $\begin{array}{l}\text { Federici et al. 1999; Riboulet-Chavey } \\
\text { et al. 2006; Housley et al. } 2008\end{array}$ \\
\hline & $\begin{array}{l}\text { Hyperactivation of } \\
\text { protein } \\
\text { phosphatase } \\
\text { PP2A }\end{array}$ & $\begin{array}{l}\text { Reduced phosphorylation } \\
\text { of IR and insulin- } \\
\text { signaling molecules }\end{array}$ & Kowluru and Matti 2012 \\
\hline Hyperinsulinemia & $\begin{array}{l}\text { Hyperactivation of } \\
\text { PHLPP1 and } \\
\text { Grb14 }\end{array}$ & $\begin{array}{l}\text { Decreased AKT Ser } 473 \\
\text { phosphorylation } \\
\text { Competition for IRS } \\
\text { binding to IR }\end{array}$ & $\begin{array}{l}\text { Cariou et al. 2004; Cozzone et al. } \\
\text { 2008; Andreozzi et al. } 2011\end{array}$ \\
\hline
\end{tabular}

Multiple molecular mechanisms of insulin resistance have been described, in addition to inhibitory Ser/Thr phosphorylation on insulin-signaling molecules (Fig. 3). Genetic mutations, dephosphorylation events, posttranslational modifications, and formation of inhibitory complexes have all been shown to cause insulin resistance.

\section{Phosphatase and Tensin Homolog}

In diabetes, mutations of PTEN have not been reported yet. However, three Japanese type-2 diabetic subjects have been identified with polymorphisms in the PTEN gene, one of which was associated with T2D. This SNP caused a higher expression rate of PTEN and reduced insulin- induced Akt activation in cells (Ishihara et al. 2003). Very recently, it has been found that individuals with PTEN haploinsufficiency are both obese and insulin sensitive, with a decreased risk of T2D but increased risk of cancer (Pal et al. 2012). The impact of this in the general population is unknown. 
J. Boucher et al.

\section{AKT and Related Targets}

A rare missense mutation $(\mathrm{R} 274 \mathrm{H})$ in Akt2 leading to loss of kinase activity has been identified in a patient with diabetes (George et al. 2004). Two other missense mutations (R208 K and R467W) have also been identified in diabetic patients, but surprisingly, these mutant forms display unaltered insulin-stimulated kinase activities in vitro (Tan et al. 2007). In type-2 diabetic patients, a gain-of-function mutation (Q84R) in Trb3 has been associated with insulin resistance and decreased insulin-stimulated Akt phosphorylation (Prudente et al. 2005, 2009). A mutation in AS160 at position 363, resulting in a premature stop codon, was identified in a patient with severe postprandial hyperinsulinemia, and acts in a dominant-negative manner to reduce glucose transport (Dash et al. 2009).

\section{Lipotoxicity}

One feature of metabolic syndrome is ectopic accumulation of lipids, especially fatty acids (FA), which is believed to cause insulin resistance via multiple mechanisms. Tissue-specific increase in lipid content in nonadipose tissues provides direct evidence of lipotoxicity. Increased hydrolysis of circulating triglycerides owing to muscle-specific overexpression of lipoprotein lipase leads to skeletal muscle insulin resistance (Ferreira et al. 2001), whereas increased lipid transport in heart or liver leads to lipotoxic cardiomyopathy and nonalcoholic fatty liver disease, respectively (Chiu et al. 2005; Koonen et al. 2007). Besides the effect of increased lipid flux on insulin sensitivity, multiple lipid intermediates have been shown to promote insulin resistance.

Elevated circulating free fatty acids (FFA) are observed in obesity and induce activation of JNK, IKK, and PKC and IRS-1 Ser-307 phosphorylation (Schenk et al. 2008). The fatty acid palmitate plays a particular role in promoting insulin resistance as it induces endoplasmic reticulum (ER) stress, cytokine production, and activates JNK (Ozcan et al. 2004; Shi et al. 2006). In addition, palmitate activates NF-кB signaling while inhibition of this pathway reverses lipid-induced insulin resistance (Kim et al. 2001a; Sinha et al. 2004). Interestingly, the detrimental effect of palmitate on skeletal muscle insulin resistance can be reversed by coinfusion with oleate, thereby changing its conversion from phospholipids and diacylglycerol (DAG) to triglycerides (Peng et al. 2011). This indicates that FFA induces insulin resistance through multiple mechanisms, and combinations of FA can influences insulin signaling and highlight the crucial interplay of lipids with respect to dietary interventions.

The lipid metabolite DAG has also been shown to induce insulin resistance. Increased muscle DAG (intramyocellular lipid) leads to muscle insulin resistance by activating PKC- $\theta$ and inducing IRS-1 Ser-307 phosphorylation (Yu et al. 2002). Conversely, reducing DAG levels in skeletal muscle and liver protects mice against high-fat-diet-induced insulin resistance (Liu et al. 2007; Ahmadian et al. 2009; Samuel et al. 2010).

Increased plasma concentration of the sphingolipid ceramide is observed in obese and diabetic patients and is associated with severe insulin resistance (Haus et al. 2009). Ceramide has been shown to induce insulin resistance via PKC and JNK activation (Westwick et al. 1995; Schenk et al. 2008) and, thus, inhibition of ceramide synthesis ameliorates insulin resistance (Holland et al. 2007). Ceramides also inhibit Akt activation by increasing the interaction of PP2A with Akt, and phosphorylation of Akt at Thr-34 by PKC $\zeta$, resulting in reduced binding of $\mathrm{PIP}_{3}$ to Akt (Teruel et al. 2001; Powell et al. 2003; Blouin et al. 2010).

In addition to effects on kinases, alteration of membrane-lipid composition affects insulin signaling. An increase in the saturated-tounsaturated FA ratio is observed in type- 2 diabetic patients and is thought to reduce membrane fluidity and insulin sensitivity (Field et al. 1990; Bakan et al. 2006). Moreover, an increase in the phosphatidylcholine (PC) to phosphatidylethanolamine $(\mathrm{PE})$ ratio in endoplasmic reticulum leads to the activation of ER stress and is associated with insulin resistance ( $\mathrm{Fu}$ et al. 2011). 
Inflammation

Obesity is characterized by the development of a chronic low-grade inflammatory state, which is considered a key component in promoting obesity-associated insulin resistance (Osborn and Olefsky 2012). Adipose tissue expansion occurs in response to caloric overload, and is associated with an increase in immune cell infiltration and a subsequent proinflammatory response (Sun et al. 2011). Two cell types are especially important in this scenario: adipocytes and macrophages, both of them capable of secreting proinflammatory cytokines and inducing insulin resistance. Increased secretion of the chemokine MCP-1 by adipocytes drives macrophage accumulation into adipose tissues and induces insulin resistance (Kamei et al. 2006). Deletion of MCP-1 or its receptor CCR2 improves insulin sensitivity and ameliorates inflammation in mice (Kanda et al. 2006; Weisberg et al. 2006). Increased secretion of cytokines, such as TNF- $\alpha$, IL1 $\beta$, or IL-6, by both immune cells and adipocytes is observed with obesity and induces insulin resistance via multiple mechanisms, including activation of Ser/Thr kinases (Ozes et al. 2001; Yuan et al. 2001; Hirosumi et al. 2002; Zhang et al. 2008a; Fan et al. 2010), decreasing IRS-1, GLUT4, and PPAR $\gamma$ expression (Rotter et al. 2003; Jager et al. 2007), or activation of SOCS3 in adipocytes (Steppan et al. 2005).

Another driving factor in obesity-associated inflammation is caused by activation of Toll-like receptor (TLR), especially activation of TLR-2 and -4. TLRs belong to the innate immune system and are generally activated by pathogen-associated molecular patterns such as LPS, and induce inflammation via activation of the NF- $\kappa$ B pathway (Akira and Takeda 2004). TLRs are ubiquitously expressed and TLR-4 is elevated in skeletal muscle (Reyna et al. 2008) and adipose tissue (Shi et al. 2006) with obesity. Interestingly, saturated FA can also activate this pathway (Lee et al. 2001; Shi et al. 2006), indicating a potential role for these receptors in obesity-driven inflammation. Thus, mice with reduced TLR-2- or TLR-4-signaling proteins (Shi et al. 2006; Kleinridders et al. 2009; Himes and Smith 2010) are protected from obesity and obesity-associated insulin resistance.

\section{Negative Regulation by Hyperglycemia}

Glucose itself, at supraphysiological concentrations, is able to alter insulin sensitivity in muscle and fat, as well as decrease insulin secretion from $\beta$ cells (Leahy et al. 1986; Hager et al. 1991). Hyperglycemia induced by decreased glucose transport in skeletal muscle impairs adipose and hepatic insulin action (Zisman et al. 2000; Kim et al. 2001b) and induces insulin resistance through several pathways, which are all believed to be linked to oxidative stress (Evans et al. 2005). Advanced glycosylation end products (AGE) inhibit insulin signaling by increasing Ser-307 phosphorylation of IRS-1 and forming methylglyoxal-IRS-1 adducts (Riboulet-Chavey et al. 2006).

Hyperglycemia increases the flux through the polyol pathway, which causes JNK activation and increases the hexosamine-biosynthetic pathway. This has been shown to promote insulin resistance in adipose tissue, skeletal muscle, liver, and pancreas in part by O-GlcNAcylation of IRS proteins (Marshall et al. 1991; Patti et al. 1999; McClain 2002; McClain et al. 2002). Furthermore, hyperglycemia also leads to $O$ GlcNAcylation of IR, which impairs receptor dimerization (Federici et al. 1999), and of Foxo1 leading to increased gluconeogenic gene expression (Housley et al. 2008).

Hyperglycemia also activates the PKC pathway by inducing de novo synthesis of DAG (Xia et al. 1994) and causes insulin resistance by forming a multimolecular complex, including receptor of AGE/IRS-1/Src, thereby activating PKC- $\alpha$ and increasing IRS- 1 Ser-307 phosphorylation (Miele et al. 2003; Cassese et al. 2008).

\section{Mitochondrial Dysfunction and ROS Formation}

Although low levels of reactive oxygen species (ROS) can enhance insulin action (KriegerBrauer et al. 1992; Mahadev et al. 2001), high concentration of ROS causes oxidative stress when unresolved. ROS formation occurs as a 
J. Boucher et al.

by-product of the electron transport chain and is a major consequence of mitochondrial dysfunction (Chang and Chuang 2010). Increased ROS levels have been observed in obese and diabetic states and can be caused by an increased metabolite flux into mitochondria, alterations in mitochondrial proteins, and reduced expression of antioxidant enzymes (West 2000; Rosen et al. 2001; Evans et al. 2005; Fridlyand and Philipson 2006). Increased oxidative stress leads to the activation of stress kinases that induce insulin resistance by serine phosphorylation of IRS proteins (Rudich et al. 1998; Evans et al. 2005; Dokken et al. 2008). Besides the aspect of ROS-mediated insulin resistance, altered mitochondrial dynamics in the form of increased mitochondrial fission leads to insulin resistance and can be rescued by inhibiting fission, which decreases the activity of p38 MAP kinase and increases IRS-1 and Akt activation (Jheng et al. 2012). Impairment of mitochondrial FA oxidation in liver can also lead to elevated DAG content, resulting in PKC- $\varepsilon$ activation and decreased IRS-2 phosphorylation and PI3-kinase activity (Koh et al. 2005; Zhang et al. 2007).

\section{ER Stress}

The ER stress response, also known as unfolded protein response (UPR), is an adaptive process to ensure proper protein folding, maturation, and quality control in the ER. The three crucial pathways of the UPR (PERK, IRE $1 \alpha$, and ATF6) are all activated with obesity and act together to reduce the burden of unfolded proteins (Hotamisligil 2010). Obese mice display enhanced PERK and IRE1 $\alpha$ activity in adipose tissue and liver, causing JNK and IKK activation and insulin resistance by phosphorylation of IRS-1 on Ser-307 (Ozcan et al. 2004, 2009; Hu et al. 2006; Zhang et al. 2008b). The transcription factor XBP-1 is activated by splicing during ER stress and increases gene expression of molecular chaperones to restore ER homeostasis. Overexpression of spliced XBP-1 reduces ER stress response, decreases activation of JNK, and increases insulin signaling by decreasing IRS-1 serine phosphorylation (Ozcan et al. 2004).

\section{CONCLUDING REMARKS}

Insulin and IGF-1 acting via specific tyrosine kinase receptors propagate signals via two main branches: the PI3K-PDK-1-Akt and the Grb2-SOS-Ras-MAPK pathways that control proliferation, differentiation, and survival at the cellular level, and growth and metabolism in organisms. These signaling pathways contain several points of regulation, signal divergence, and cross talk with other signaling cascades that define critical nodes (Taniguchi et al. 2006a). The complexity of this signaling system is essential to mediate the variety of insulin and IGF-1 biological responses. Many steps are negatively regulated by action of phosphatases or inhibitory proteins. One of the great challenges remaining is deciphering the complexity of insulin-resistance pathogenesis. Causes of insulin resistance are numerous and the mechanisms are multifactorial. In rare cases, the cause is genetic, but in most others, insulin resistance is triggered by cellular perturbations, such as lipotoxicity, inflammation, glucotoxicity, mitochondrial dysfunction, and ER stress, which lead to deregulation of genes and inhibitory protein modifications, resulting in impaired insulin and IGF-1 action. Identifying new molecules that impact insulin signaling and new levels of control, as well as better understanding the causes and mechanisms leading to insulin resistance, will be essential for a more effective treatment of type-2 diabetes and associated diseases.

\section{REFERENCES}

Aguirre V, Uchida T, Yenush L, Davis R, White MF. 2000. The c-Jun $\mathrm{NH}(2)$-terminal kinase promotes insulin resistance during association with insulin receptor substrate-1 and phosphorylation of Ser(307). J Biol Chem 275: 90479054.

Aguirre V, Werner ED, Giraud J, Lee YH, Shoelson SE, White MF. 2002. Phosphorylation of Ser307 in insulin receptor substrate-1 blocks interactions with the insulin receptor and inhibits insulin action. J Biol Chem 277: 1531-1537.

Ahmadian M, Duncan RE, Varady KA, Frasson D, Hellerstein MK, Birkenfeld AL, Samuel VT, Shulman GI, Wang Y, Kang C, et al. 2009. Adipose overexpression of desnutrin promotes fatty acid use and attenuates diet-induced obesity. Diabetes 58: 855-866.

Akira S, Takeda K. 2004. Toll-like receptor signalling. Nat Rev Immunol 4: 499-511. 
Alessi DR, James SR, Downes CP, Holmes AB, Gaffney PR, Reese CB, Cohen P. 1997. Characterization of a 3-phosphoinositide-dependent protein kinase, which phosphorylates and activates protein kinase $\mathrm{B} \alpha$. Curr Biol 7: 261-269.

Almind K, Inoue G, Pedersen O, Kahn CR. 1996. A common amino acid polymorphism in insulin receptor substratecauses impaired insulin signaling. Evidence from transfection studies. J Clin Invest 97: 2569-2575.

Almind K, Delahaye L, Hansen T, Van Obberghen E, Pedersen O, Kahn CR. 2002. Characterization of the Met326Ile variant of phosphatidylinositol 3-kinase $\mathrm{p} 85 \alpha$. Proc Nat Acad Sci 99: 2124-2128.

An D, Toyoda T, Taylor EB, Yu H, Fujii N, Hirshman MF, Goodyear LJ. 2010. TBC1D1 regulates insulin- and contraction-induced glucose transport in mouse skeletal muscle. Diabetes 59: 1358-1365.

Andreozzi F, Procopio C, Greco A, Mannino GC, Miele C, Raciti GA, Iadicicco C, Beguinot F, Pontiroli AE, Hribal $\mathrm{ML}$, et al. 2011. Increased levels of the Akt-specific phosphatase $\mathrm{PH}$ domain leucine-rich repeat protein phosphatase (PHLPP)-1 in obese participants are associated with insulin resistance. Diabetologia 54: 1879-1887.

Araki E, Lipes MA, Patti ME, Bruning JC, Haag B III, Johnson RS, Kahn CR. 1994. Alternative pathway of insulin signalling in mice with targeted disruption of the IRS-1 gene. Nature 372: 186-190.

Bai D, Ueno L, Vogt PK. 2009. Akt-mediated regulation of NF- $\kappa \mathrm{B}$ and the essentialness of NF- $\mathrm{B}$ for the oncogenicity of PI3K and Akt. Int J Cancer 125: 2863-2870.

Baier LJ, Wiedrich C, Hanson RL, Bogardus C. 1998. Variant in the regulatory subunit of phosphatidylinositol 3-kinase ( $p 85 \alpha)$ : Preliminary evidence indicates a potential role of this variant in the acute insulin response and type 2 diabetes in Pima women. Diabetes 47: 973-975.

Bailyes EM, Nave BT, Soos MA, Orr SR, Hayward AC, Siddle K. 1997. Insulin receptor/IGF-I receptor hybrids are widely distributed in mammalian tissues: Quantification of individual receptor species by selective immunoprecipitation and immunoblotting. Biochem J 327: 209215.

Bakan E, Yildirim A, Kurtul N, Polat MF, Dursun H, Cayir K. 2006. Effects of type 2 diabetes mellitus on plasma fatty acid composition and cholesterol content of erythrocyte and leukocyte membranes. Acta Diabetol 43: 109-113.

Barroso I, Luan J, Middelberg RP, Harding AH, Franks PW, Jakes RW, Clayton D, Schafer AJ, O'Rahilly S, Wareham NJ. 2003. Candidate gene association study in type 2 diabetes indicates a role for genes involved in $\beta$-cell function as well as insulin action. PLoS Biol 1: E20.

Baumann CA, Ribon V, Kanzaki M, Thurmond DC, Mora S, Shigematsu S, Bickel PE, Pessin JE, Saltiel AR. 2000. CAP defines a second signalling pathway required for insulinstimulated glucose transport. Nature 407: 202-207.

Bayascas JR. 2010. PDK1: The major transducer of PI 3kinase actions. Curr Top Microbiol Immunol 346: 9-29.

Belfiore A, Frasca F, Pandini G, Sciacca L, Vigneri R. 2009. Insulin receptor isoforms and insulin receptor/insulinlike growth factor receptor hybrids in physiology and disease. Endocr Rev 30: 586-623.

Benyoucef S, Surinya KH, Hadaschik D, Siddle K. 2007. Characterization of insulin/IGF hybrid receptors: Con- tributions of the insulin receptor L2 and Fn1 domains and the alternatively spliced exon 11 sequence to ligand binding and receptor activation. Biochem J 403: 603-613.

Bernal D, Almind K, Yenush L, Ayoub M, Zhang Y, Rosshani L, Larsson C, Pedersen O, White MF. 1998. IRS-2 amino acid polymorphisms are not associated with random type 2 diabetes amoung caucasians. Diabetes 47: 976-979.

Bezy O, Tran TT, Pihlajamaki J, Suzuki R, Emanuelli B, Winnay J, Mori MA, Haas J, Biddinger SB, Leitges M, et al. 2011. PKC $\delta$ regulates hepatic insulin sensitivity and hepatosteatosis in mice and humans. J Clin Invest 121: $2504-2517$.

Bjornholm M, He AR, Attersand A, Lake S, Liu SCH, Lienhard GE, Taylor S, Arner P, Zierath JR. 2002. Absence of functional insulin receptor substrate-3 (IRS-3) gene in humans. Diabetologia 45: 1697-1702.

Blouin CM, Prado C, Takane KK, Lasnier F, Garcia-Ocana A, Ferre P, Dugail I, Hajduch E. 2010. Plasma membrane subdomain compartmentalization contributes to distinct mechanisms of ceramide action on insulin signaling. Diabetes 59: 600-610.

Bollag GE, Roth RA, Beaudoin J, Mochly Rosen D, Koshland DE Jr. 1986. Protein kinase C directly phosphorylates the insulin receptor in vitro and reduces its protein-tyrosine kinase activity. Proc Natl Acad Sci 83: 5822-5824.

Boucher J, Tseng YH, Kahn CR. 2010. Insulin and insulinlike growth factor-1 receptors act as ligand-specific amplitude modulators of a common pathway regulating gene transcription. J Biol Chem 285: 17235-17245.

Boura-Halfon S, Zick Y. 2009. Phosphorylation of IRS proteins, insulin action, and insulin resistance. Am J Physiol Endocrinol Metab 296: E581-E591.

Bouzakri K, Zachrisson A, Al Khalili L, Zhang BB, Koistinen HA, Krook A, Zierath JR. 2006. siRNA-based gene silencing reveals specialized roles of IRS-1/Akt2 and IRS-2/ Akt1 in glucose and lipid metabolism in human skeletal muscle. Cell Metab 4: 89-96.

Bozulic L, Surucu B, Hynx D, Hemmings BA. 2008. PKB $\alpha$ / Aktl acts downstream of DNA-PK in the DNA doublestrand break response and promotes survival. Mol Cell 30: 203-213.

Brady MJ, Saltiel AR. 2001. The role of protein phosphatase1 in insulin action. Recent Prog Horm Res 56: 157-173.

Brognard J, Newton AC. 2008. PHLiPPing the switch on Akt and protein kinase $\mathrm{C}$ signaling. Trends Endocrinol Metab 19: $223-230$.

Bruhn MA, Pearson RB, Hannan RD, Sheppard KE. 2010. Second AKT: The rise of SGK in cancer signalling. Growth Factors 28: 394-408.

Burguete-Garcia AI, Cruz-Lopez M, Madrid-Marina V, Lopez-Ridaura R, Hernandez-Avila M, Cortina B, Gomez RE, Velasco-Mondragon E. 2010. Association of Gly972Arg polymorphism of IRS1 gene with type 2 diabetes mellitus in lean participants of a national health survey in Mexico: A candidate gene study. Metabolism 59: $38-45$.

Burke JE, Vadas O, Berndt A, Finegan T, Perisic O, Williams RL. 2011. Dynamics of the phosphoinositide 3-kinase p1108 interaction with $\mathrm{p} 85 \alpha$ and membranes reveals aspects of regulation distinct from $\mathrm{p} 110 \alpha$. Structure 19: $1127-1137$. 
J. Boucher et al.

Cai D, Dhe-Paganon S, Melendez PA, Lee J, Shoelson SE. 2003. Two new substrates in insulin signaling, IRS5/ DOK4 and IRS6/DOK5. J Biol Chem 278: 25323-25330.

Cantley LC, Neel BG. 1999. New insights into tumor suppression: PTEN suppresses tumor formation by restraining the phosphoinositide 3-kinase/AKT pathway. Proc Natl Acad Sci 96: 4240-4245.

Cardone MH, Roy N, Stennicke HR, Salvesen GS, Franke TF, Stanbridge E, Frisch S, Reed JC. 1998. Regulation of cell death protease caspase- 9 by phosphorylation. Science 282: $1318-1321$

Cariou B, Capitaine N, Le M, Vega VN, Bereziat V, Kergoat M, Laville M, Girard J, Vidal H, Burnol AF. 2004. Increased adipose tissue expression of Grb14 in several models of insulin resistance. FASEB J 18: 965-967.

Carracedo A, Pandolfi PP. 2008. The PTEN-PI3K pathway: Of feedbacks and cross-talks. Oncogene 27: 5527-5541.

Cassese A, Esposito I, Fiory F, Barbagallo AP, Paturzo F, Mirra P, Ulianich L, Giacco F, Iadicicco C, Lombardi A, et al. 2008. In skeletal muscle advanced glycation end products (AGEs) inhibit insulin action and induce the formation of multimolecular complexes including the receptor for AGEs. J Biol Chem 283: 36088-36099.

Chagpar RB, Links PH, Pastor MC, Furber LA, Hawrysh AD, Chamberlain MD, Anderson DH. 2010. Direct positive regulation of PTEN by the $\mathrm{p} 85$ subunit of phosphatidylinositol 3-kinase. Proc Natl Acad Sci 107: 5471-5476.

Chakraborty A, Koldobskiy MA, Bello NT, Maxwell M, Potter JJ, Juluri KR, Maag D, Kim S, Huang AS, Dailey MJ, et al. 2010. Inositol pyrophosphates inhibit Akt signaling, thereby regulating insulin sensitivity and weight gain. Cell 143: 897-910.

Chang YC, Chuang LM. 2010. The role of oxidative stress in the pathogenesis of type 2 diabetes: From molecular mechanism to clinical implication. Am J Transl Res 2: $316-331$.

Cheng X, Xia W, Yang JY, Hsu JL, Lang JY, Chou CK, Du Y, Sun HL, Wyszomierski SL, Mills GB, et al. 2010. Activation of murine double minute 2 by Akt in mammary epithelium delays mammary involution and accelerates mammary tumorigenesis. Cancer Res 70: 7684-7689.

Chin JE, Dickens M, Tavare JM, Roth RA. 1993. Overexpression of protein kinase $\mathrm{C}$ isoenzymes $\alpha, \beta$ I, $\gamma$, and $\varepsilon$ in cells overexpressing the insulin receptor. Effects on receptor phosphorylation and signaling. J Biol Chem 268: 6338-6347.

Chiu HC, Kovacs A, Blanton RM, Han X, Courtois M, Weinheimer CJ, Yamada KA, Brunet S, Xu H, Nerbonne JM, et al. 2005. Transgenic expression of fatty acid transport protein 1 in the heart causes lipotoxic cardiomyopathy. Circ Res 96: 225-233.

Cho H, Mu J, Kim JK, Thorvaldsen JL, Chu Q, Crenshaw EB III, Kaestner KH, Bartolomei MS, Shulman GI, Birnbaum MJ. 2001. Insulin resistance and a diabetes mellitus-like syndrome in mice lacking the protein kinase Akt2 (PKB $\beta$ ). Science 292: 1728-1731.

Clement S, Krause U, Desmedt F, Tanti JF, Behrends J, Pesesse X, Sasaki T, Penninger J, Doherty M, Malaisse W, et al. 2001. The lipid phosphatase SHIP2 controls insulin sensitivity. Nature 409: 92-97.
Cochran E, Musso C, Gorden P. 2005. The use of U-500 in patients with extreme insulin resistance. Diabetes Care 28: $1240-1244$.

Cooney GJ, Lyons RJ, Crew AJ, Jensen TE, Molero JC, Mitchell CJ, Biden TJ, Ormandy CJ, James DE, Daly RJ. 2004. Improved glucose homeostasis and enhanced insulin signalling in Grb14-deficient mice. EMBO J 23: 582-593.

Copps KD, Hancer NJ, Opare-Ado L, Qiu W, Walsh C, White MF. 2010. Irs1 serine 307 promotes insulin sensitivity in mice. Cell Metab 11: 84-92.

Cozzone D, Frojdo S, Disse E, Debard C, Laville M, Pirola L, Vidal H. 2008. Isoform-specific defects of insulin stimulation of Akt/protein kinase B (PKB) in skeletal muscle cells from type 2 diabetic patients. Diabetologia 51:512521.

Dash S, Sano H, Rochford JJ, Semple RK, Yeo G, Hyden CS, Soos MA, Clark J, Rodin A, Langenberg C, et al. 2009. A truncation mutation in TBC1D4 in a family with acanthosis nigricans and postprandial hyperinsulinemia. Proc Natl Acad Sci 106: 9350-9355.

Datta SR, Dudek H, Tao X, Masters S, Fu H, Gotoh Y, Greenberg ME. 1997. Akt phosphorylation of BAD couples survival signals to the cell-intrinsic death machinery. Cell 91: 231-241.

De Fea K, Roth RA. 1997a. Modulation of insulin receptor substrate-1 tyrosine phosphorylation and function by mitogen-activated protein kinase. J Biol Chem 272: 31400-31406.

De Fea K, Roth RA. 1997b. Protein kinase C modulation of insulin receptor substrate- 1 tyrosine phosphorylation requires serine 612. Biochemistry 36: 12939-12947.

Degerman E, Ahmad F, Chung YW, Guirguis E, Omar B, Stenson L, Manganiello V. 2011. From PDE3B to the regulation of energy homeostasis. Curr Opin Pharmacol 11: 676-682.

Deyev IE, Sohet F, Vassilenko KP, Serova OV, Popova NV, Zozulya SA, Burova EB, Houillier P, Rzhevsky DI, Berchatova AA, et al. 2011. Insulin receptor-related receptor as an extracellular alkali sensor. Cell Metab 13: 679-689.

Dimmeler S, Fleming I, Fisslthaler B, Hermann C, Busse R, Zeiher AM. 1999. Activation of nitric oxide synthase in endothelial cells by Akt-dependent phosphorylation. $\mathrm{Na}$ ture 399: 601-605.

Dokken BB, Saengsirisuwan V, Kim JS, Teachey MK, Henriksen EJ. 2008. Oxidative stress-induced insulin resistance in rat skeletal muscle: Role of glycogen synthase kinase-3. Am J Physiol Endocrinol Metab 294: E615E621.

Du K, Herzig S, Kulkarni RN, Montminy M. 2003. TRB3: A tribbles homolog that inhibits Akt/PKB activation by insulin in liver. Science 300: 1574-1577.

Dunaif A, Xia J, Book CB, Schenker E, Tang Z. 1995. Excessive insulin receptor serine phosphorylation in cultured fibroblasts and in skeletal muscle. A potential mechanism for insulin resistance in the polycystic ovary syndrome. $J$ Clin Invest 96: 801-810.

Duvel K, Yecies JL, Menon S, Raman P, Lipovsky AI, Souza AL, Triantafellow E, Ma Q, Gorski R, Cleaver S, et al. 2010. Activation of a metabolic gene regulatory network downstream of mTOR complex 1. Mol Cell 39: 171-183. 
Elchebly M, Payette P, Michaliszyn E, Cromlish W, Collins S, Loy AL, Normandin DCA, imms-Hagen J, Chan C, Ramachandran C, et al. 1999. Increased insulin sensitivity and obesity resistance in mice lacking the protein tyrosine phosphatase-1B gene. Science 283: 1544-1548.

Emanuelli B, Peraldi P, Filloux C, Sawka-Verhelle D, Hilton D, Van OE. 2000. SOCS-3 is an insulin-induced negative regulator of insulin signaling. J Biol Chem 275: 1598515991.

Emanuelli B, Peraldi P, Filloux C, Chavey C, Freidinger L, Hilton DJ, Hotamisligil GS, Van OE. 2001. SOCS-3 inhibits insulin signaling and is up-regulated in response to tumor necrosis factor- $\alpha$ in the adipose tissue of obese mice. J Biol Chem 276: 47944-47949.

Esposito DL, Li Y, Vanni C, Mammarella S, Veschi S, Della LF, Mariani-Costantini R, Battista P, Quon MJ, Cama A. 2003. A novel T608R missense mutation in insulin receptor substrate- 1 identified in a subject with type 2 diabetes impairs metabolic insulin signaling. J Clin Endocrinol Metab 88: 1468-1475.

Evans JL, Maddux BA, Goldfine ID. 2005. The molecular basis for oxidative stress-induced insulin resistance. Antioxid Redox Signal 7: 1040-1052.

Fan Y, Yu Y, Shi Y, Sun W, Xie M, Ge N, Mao R, Chang A, Xu G, Schneider MD, et al. 2010. Lysine 63-linked polyubiquitination of TAK1 at lysine 158 is required for tumor necrosis factor $\alpha$ - and interleukin- $1 \beta$-induced IKK/NF-кB and JNK/AP-1 activation. J Biol Chem 285: $5347-5360$.

Fantin VR, Lavan BE, Wang Q, Jenkins NA, Gilbert DJ, Copeland NG, Keller SR, Lienhard GE. 1999. Cloning, tissue expression, and chromosomal location of the mouse insulin receptor substrate 4 gene. Endocrinology 140: $1329-1337$.

Fantin VR, Wang Q, Lienhard GE, Keller SR. 2000. Mice lacking insulin receptor substrate 4 exhibit mild defects in growth, reproduction, and glucose homeostasis. Am J Physiol Endocrinol Metab 278: E127-E133.

Farese RV, Sajan MP. 2010. Metabolic functions of atypical protein kinase C: "Good" and "bad" as defined by nutritional status. Am J Physiol Endocrinol Metab 298: E385E394.

Farese RV, Sajan MP, Yang H, Li P, Mastorides S, Gower WR Jr, Nimal S, Choi CS, Kim S, Shulman GI, et al. 2007. Muscle-specific knockout of PKC- $\lambda$ impairs glucose transport and induces metabolic and diabetic syndromes. J Clin Invest 117: 2289-2301.

Federici M, Giaccari A, Hribal ML, Giovannone B, Lauro D, Morviducci L, Pastore L, Tamburrano G, Lauro R, Sesti G. 1999. Evidence for glucose/hexosamine in vivo regulation of insulin/IGF-I hybrid receptor assembly. Diabetes 48: $2277-2285$.

Ferreira LD, Pulawa LK, Jensen DR, Eckel RH. 2001. Overexpressing human lipoprotein lipase in mouse skeletal muscle is associated with insulin resistance. Diabetes 50: $1064-1068$.

Field CJ, Ryan EA, Thomson AB, Clandinin MT. 1990. Diet fat composition alters membrane phospholipid composition, insulin binding, and glucose metabolism in adipocytes from control and diabetic animals. J Biol Chem 265: $11143-11150$.
Florez JC, Sjogren M, Burtt N, Orho-Melander M, Schayer S, Sun M, Almgren P, Lindblad U, Tuomi T, Gaudet D, et al. 2004. Association testing in 9,000 people fails to confirm the association of the insulin receptor substrate-1 G972R polymorphism with type 2 diabetes. $D i$ abetes 53: 3313-3318.

Frasca F, Pandini G, Scalia P, Sciacca L, Mineo R, Costantino A, Goldfine ID, Belfiore A, Vigneri R. 1999. Insulin receptor isoform A, a newly recognized, high-affinity insulin-like growth factor II receptor in fetal and cancer cells. Mol Cell Biol 19: 3278-3288.

Fridlyand LE, Philipson LH. 2006. Reactive species and early manifestation of insulin resistance in type 2 diabetes. Diabetes Obes Metab 8: 136-145.

Fu S, Yang L, Li P, Hofmann O, Dicker L, Hide W, Lin X, Watkins SM, Ivanov AR, Hotamisligil GS. 2011. Aberrant lipid metabolism disrupts calcium homeostasis causing liver endoplasmic reticulum stress in obesity. Nature 473: $528-531$.

Fulton D, Gratton JP, McCabe TJ, Fontana J, Fujio Y, Walsh K, Franke TF, Papapetropoulos A, Sessa WC. 1999. Regulation of endothelium-derived nitric oxide production by the protein kinase Akt. Nature 399: 597-601.

Gao Z, Hwang D, Bataille F, Lefevre M, York D, Quon M, Ye J. 2002. Serine phosphorylation of insulin receptor substrate 1 (IRS-1) by inhibitor KB kinase (IKK) complex. J Biol Chem 277: 48115-48121.

Gardai SJ, Hildeman DA, Frankel SK, Whitlock BB, Frasch SC, Borregaard N, Marrack P, Bratton DL, Henson PM. 2004. Phosphorylation of Bax Ser 184 by Akt regulates its activity and apoptosis in neutrophils. J Biol Chem 279: 21085-21095.

George S, Rochford JJ, Wolfrum C, Gray SL, Schinner S, Wilson JC, Soos MA, Murgatroyd PR, Williams RM, Acerini CL, et al. 2004. A family with severe insulin resistance and diabetes due to a mutation in AKT2. Science 304: $1325-1328$.

Goldstein BJ, Ahmad F, Ding W, Li PM, Zhang WR. 1998. Regulation of the insulin signalling pathway by cellular protein-tyrosine phosphatases. Mol Cell Biochem 182: 91-99.

Gual P, Gonzalez T, Gremeaux T, Barres R, Marchand-Brustel Y, Tanti JF. 2003. Hyperosmotic stress inhibits insulin receptor substrate- 1 function by distinct mechanisms in 3T3-L1 adipocytes. J Biol Chem 278: 26550-26557.

Hager SR, Jochen AL, Kalkhoff RK. 1991. Insulin resistance in normal rats infused with glucose for $72 \mathrm{~h}$. Am J Physiol 260: E353-E362.

Hanke S, Mann M. 2009. The phosphotyrosine interactome of the insulin receptor family and its substrates IRS-1 and IRS-2. Mol Cell Proteomics 8: 519-534.

Harrington LS, Findlay GM, Gray A, Tolkacheva T, Wigfield S, Rebholz H, Barnett J, Leslie NR, Cheng S, Shepherd PR, et al. 2004. The TSC1-2 tumor suppressor controls insulin-PI3K signaling via regulation of IRS proteins. $J$ Cell Biol 166: 213-223.

Haruta T, Imamura T, Iwanishi M, Egawa K, Goji K, Kobayashi M. 1995. Amplification and analysis of promoter region of insulin receptor gene in a patient with leprechaunism associated with severe insulin resistance. $\mathrm{Me}$ tabolism 44: 430-437. 
J. Boucher et al.

Haus JM, Kashyap SR, Kasumov T, Zhang R, Kelly KR, DeFronzo RA, Kirwan JP. 2009. Plasma ceramides are elevated in obese subjects with type 2 diabetes and correlate with the severity of insulin resistance. Diabetes 58: 337-343.

Himes RW, Smith CW. 2010. Tlr2 is critical for diet-induced metabolic syndrome in a murine model. FASEB J 24: 731-739.

Hirosumi J, Tuncman G, Chang L, Gorgun CZ, Uysal KT, Maeda K, Karin M, Hotamisligil GS. 2002. A central role for JNK in obesity and insulin resistance. Nature 420: 333-336.

Holland WL, Brozinick JT, Wang LP, Hawkins ED, Sargent KM, Liu Y, Narra K, Hoehn KL, Knotts TA, Siesky A, et al. 2007. Inhibition of ceramide synthesis ameliorates glucocorticoid-, saturated-fat-, and obesity-induced insulin resistance. Cell Metab 5: 167-179.

Holt LJ, Siddle K. 2005. Grb10 and Grb14: Enigmatic regulators of insulin action — and more? Biochem J 388: 393406.

Holt LJ, Lyons RJ, Ryan AS, Beale SM, Ward A, Cooney GJ, Daly RJ. 2009. Dual ablation of Grb10 and Grb14 in mice reveals their combined role in regulation of insulin signaling and glucose homeostasis. Mol Endocrinol 23: 1406-1414.

Hotamisligil GS. 2010. Endoplasmic reticulum stress and the inflammatory basis of metabolic disease. Cell 140: 900-917.

Housley MP, Rodgers JT, Udeshi ND, Kelly TJ, Shabanowitz J, Hunt DF, Puigserver P, Hart GW. 2008. O-GlcNAc regulates FoxO activation in response to glucose. J Biol Chem 283: $16283-16292$.

Hribal ML, Tornei F, Pujol A, Menghini R, Barcaroli D, Lauro D, Amoruso R, Lauro R, Bosch F, Sesti G, et al. 2008. Transgenic mice overexpressing human G972R IRS-1 show impaired insulin action and insulin secretion. J Cell Mol Med 12: 2096-2106.

Hsu PP, Kang SA, Rameseder J, Zhang Y, Ottina KA, Lim D, Peterson TR, Choi Y, Gray NS, Yaffe MB, et al. 2011. The mTOR-regulated phosphoproteome reveals a mechanism of mTORC1-mediated inhibition of growth factor signaling. Science 332: 1317-1322.

Hu P, Han Z, Couvillon AD, Kaufman RJ, Exton JH. 2006. Autocrine tumor necrosis factor $\alpha$ links endoplasmic reticulum stress to the membrane death receptor pathway through IRE1 $\alpha$-mediated NF- $\mathrm{B}$ activation and downregulation of TRAF2 expression. Mol Cell Biol 26: 30713084.

Huang C, Thirone AC, Huang X, Klip A. 2005. Differential contribution of insulin receptor substrates 1 versus 2 to insulin signaling and glucose uptake in 16 myotubes. $J$ Biol Chem 280: 19426-19435.

Ishihara H, Sasaoka T, Kagawa S, Murakami S, Fukui K, Kawagishi Y, Yamazaki K, Sato A, Iwata M, Urakaze M, et al. 2003. Association of the polymorphisms in the $5^{\prime}$ untranslated region of PTEN gene with type 2 diabetes in a Japanese population. Growth Regul 554: 450-454.

Jager J, Gremeaux T, Cormont M, Le Marchand-Brustel Y, Tanti JF. 2007. Interleukin- $1 \beta$-induced insulin resistance in adipocytes through down-regulation of insulin receptor substrate-1 expression. Endocrinology 148: 241-251.
Jheng HF, Tsai PJ, Guo SM, Kuo LH, Chang CS, Su IJ, Chang CR, Tsai YS. 2012. Mitochondrial fission contributes to mitochondrial dysfunction and insulin resistance in skeletal muscle. Mol Cell Biol 32: 309-319.

Jia S, Liu Z, Zhang S, Liu P, Zhang L, Lee SH, Zhang J, Signoretti S, Loda M, Roberts TM, et al. 2008. Essential roles of PI3K-p110 $\beta$ in cell growth, metabolism and tumorigenesis. Nature 454: 776-779.

Kagawa S, Soeda Y, Ishihara H, Oya T, Sasahara M, Yaguchi S, Oshita R, Wada T, Tsuneki H, Sasaoka T. 2008. Impact of transgenic overexpression of SH2-containing inositol $5^{\prime}$ phosphatase 2 on glucose metabolism and insulin signaling in mice. Endocrinology 149: 642-650.

Kahn CR, Flier JS, Bar RS, Archer JA, Gorden P, Martin MM, Roth J. 1976. The syndromes of insulin resistance and acanthosis nigricans. Insulin-receptor disorders in man. N Engl J Med 294: 739-745.

Kamei N, Tobe K, Suzuki R, Ohsugi M, Watanabe T, Kubota N, Ohtsuka-Kowatari N, Kumagai K, Sakamoto K, Kobayashi M, et al. 2006. Overexpression of monocyte chemoattractant protein-1 in adipose tissues causes macrophage recruitment and insulin resistance. J Biol Chem 281: 26602-26614.

Kanda H, Tateya S, Tamori Y, Kotani K, Hiasa K, Kitazawa R, Kitazawa S, Miyachi H, Maeda S, Egashira K, et al. 2006. MCP-1 contributes to macrophage infiltration into adipose tissue, insulin resistance, and hepatic steatosis in obesity. J Clin Invest 116: 1494-1505.

Karasik A, Rothenberg PL, Yamada K, White MF, Kahn CR. 1990. Increased protein kinase C activity is linked to reduced insulin receptor autophosphorylation in liver of starved rats. J Biol Chem 265: 10226-10231.

Kim JK, Kim YJ, Fillmore JJ, Chen Y, Moore I, Lee J, Yuan M, Li ZW, Karin M, Perret P, et al. 2001a. Prevention of fatinduced insulin resistance by salicylate. J Clin Invest 108: 437-446.

Kim JK, Zisman A, Fillmore JJ, Peroni OD, Kotani K, Perret P, Zong H, Kahn CR, Kahn BB, Shulman GI. 2001b. Glucose toxicity and the development of diabetes in mice with muscle-specific inactivation of GLUT4. J Clin Invest 108: 153-160.

Kim JK, Fillmore JJ, Sunshine MJ, Albrecht B, Higashimori T, Kim DW, Liu ZX, Soos TJ, Cline GW, O’Brien WR, et al. 2004a. PKC- $\theta$ knockout mice are protected from fatinduced insulin resistance. J Clin Invest 114: 823-827.

Kim KH, Song JJ, Yoo EJ, Choe SS, Park SD, Kim JB. $2004 b$. Regulatory role of glycogen synthase kinase 3 for criptional activity of ADD1/SREBP1c. J Biol Chem 279: 51999-52006.

Kitamura T, Kitamura Y, Kuroda S, Hino Y, Ando M, Kotani K, Konishi H, Matsuzaki H, Kikkawa U, Ogawa W, et al. 1999. Insulin-induced phosphorylation and activation of cyclic nucleotide phosphodiesterase $3 \mathrm{~B}$ by the serinethreonine kinase Akt. Mol Cell Biol 19: 6286-6296.

Klaman LD, Boss O, Peroni OD, Kim JK, Martino JL, Zabolotny JM, Moghal N, Lubkin M, Kim YB, Sharpe AH, et al. 2000. Increased energy expenditure, decreased adiposity, and tissue-specific insulin sensitivity in proteintyrosine phosphatase 1B-deficient mice. Mol Cell Biol 20: 5479-5489.

Kleinridders A, Schenten D, Konner AC, Belgardt BF, Mauer J, Okamura T, Wunderlich FT, Medzhitov R, Bruning JC. 
2009. MyD88 signaling in the CNS is required for development of fatty acid-induced leptin resistance and dietinduced obesity. Cell Metab 10: 249-259.

Koh EH, Lee WJ, Kim MS, Park JY, Lee IK, Lee KU. 2005. Intracellular fatty acid metabolism in skeletal muscle and insulin resistance. Curr Diabetes Rev 1: 331-336.

Koo SH, Satoh H, Herzig S, Lee CH, Hedrick S, Kulkarni R, Evans RM, Olefsky J, Montminy M. 2004. PGC-1 promotes insulin resistance in liver through PPAR- $\alpha$-dependent induction of TRB-3. Nat Med 10: 530-534.

Koonen DP, Jacobs RL, Febbraio M, Young ME, Soltys CL, Ong H, Vance DE, Dyck JR. 2007. Increased hepatic CD36 expression contributes to dyslipidemia associated with diet-induced obesity. Diabetes 56: 2863-2871.

Kowluru A, Matti A. 2012. Hyperactivation of protein phosphatase $2 \mathrm{~A}$ in models of glucolipotoxicity and diabetes: Potential mechanisms and functional consequences. Biochem Pharmacol 84: 591-597.

Krieger-Brauer HI Kather H. 1992. Human fat cells possess a plasma membrane-bound $\mathrm{H}_{2} \mathrm{O}_{2}$-generating system that is activated by insulin via a mechanism bypassing the receptor kinase. J Clin Invest 89: 1006-1013.

Kurlawalla-Martinez C, Stiles B, Wang Y, Devaskar SU, Kahn BB, Wu H. 2005. Insulin hypersensitivity and resistance to streptozotocin-induced diabetes in mice lacking PTEN in adipose tissue. Mol Cell Biol 25: 2498-2510.

Laustsen PG, Michael MD, Crute BE, Cohen SE, Ueki K, Kulkarni RN, Keller SR, Lienhard GE, Kahn CR. 2002. Lipoatrophic diabetes in Irs $1^{-/-} / \mathrm{Irs}^{-/-}$double knockout mice. Genes Dev 16: 3213-3222.

Lavan BE, Fantin VR, Chang ET, Lane WS, Keller SR, Lienhard GE. 1997a. A novel 160-kDa phosphotyrosine protein in insulin-treated embryonic kidney cells is a new member of the insulin receptor substrate family. J Biol Chem 272: 21403-21407.

Lavan BE, Lane WS, Lienhard GE. 1997b. The 60-kDa phosphotyrosine protein in insulin-treated adipocytes is a new member of the insulin receptor substrate family. J Biol Chem 272: 11439-11443.

Leahy JL, Cooper HE, Deal DA, Weir DG. 1986. Chronic hyperglycemia is associated with impaired glucose influence on insulin secretion. A study in normal rats using chronic in vivo glucose infusions. J Clin Invest 77: 908915.

Lee JY, Sohn KH, Rhee SH, Hwang D. 2001. Saturated fatty acids, but not unsaturated fatty acids, induce the expression of cyclooxygenase-2 mediated through Toll-like receptor 4. J Biol Chem 276: 16683-16689.

Lewis RE, Cao L, Perregaux D, Czech MP. 1990. Threonine 1336 of the human insulin receptor is a major target for phosphorylation by protein kinase C. Biochemistry 29: 1807-1813.

Li Y, Soos TJ, Li X, Wu J, Degennaro M, Sun X, Littman DR, Birnbaum MJ, Polakiewicz RD. 2004. Protein kinase C $\theta$ inhibits insulin signaling by phosphorylating IRS1 at Ser(1101). J Biol Chem 279: 45304-45307.

Li X, Monks B, Ge Q, Birnbaum MJ. 2007. Akt/PKB regulates hepatic metabolism by directly inhibiting PGC-1 $\alpha$ cription coactivator. Nature 447: 1012-1016.

Liu L, Zhang Y, Chen N, Shi X, Tsang B, Yu BH. 2007. Upregulation of myocellular DGAT1 augments triglycer- ide synthesis in skeletal muscle and protects against fatinduced insulin resistance. J Clin Invest 117: 1679-1689.

Lu M, Wan M, Leavens KF, Chu Q, Monks BR, Fernandez S, Ahima RS, Ueki K, Kahn CR, Birnbaum MJ. 2012. Insulin regulates liver metabolism in vivo in the absence of hepatic Akt and Foxo1. Nat Med 18: 388-395.

Mack E, Ziv E, Reuveni H, Kalman R, Niv MY, Jorns A, Lenzen S, Shafrir E. 2008. Prevention of insulin resistance and $\beta$-cell loss by abrogating PKC $\varepsilon$-induced serine phosphorylation of muscle IRS-1 in Psammomys obesus. Diabetes Metab Res Rev 24: 577-584.

Mahadev K, Zilbering A, Zhu L, Goldstein BJ. 2001. Insulinstimulated hydrogen peroxide reversibly inhibits proteintyrosine phosphatase $1 \mathrm{~b}$ in vivo and enhances the early insulin action cascade. J Biol Chem 276: 21938-21942.

Manning BD, Cantley LC. 2007. AKT/PKB signaling: Navigating downstream. Cell 129: 1261-1274.

Marshall S, Bacote V, Traxinger RR. 1991. Discovery of a metabolic pathway mediating glucose-induced desensitization of the glucose transport system. Role of hexosamine biosynthesis in the induction of insulin resistance. J Biol Chem 266: 4706-4712.

Martinez-Gomez LE, Cruz M, Martinez-Nava GA, MadridMarina V, Parra E, Garcia-Mena J, Espinoza-Rojo M, Estrada-Velasco BI, Piza-Roman LF, Aguilera P, et al. 2011. A replication study of the IRS1, CAPN10, TCF7L2, and PPARG gene polymorphisms associated with type 2 diabetes in two different populations of Mexico. Ann Hum Genet 75: 612-620.

Matsumoto M, Ogawa W, Akimoto K, Inoue H, Miyake K, Furukawa K, Hayashi Y, Iguchi H, Matsuki Y, Hiramatsu $\mathrm{R}$, et al. 2003. PKC $\lambda$ in liver mediates insulin-induced SREBP-1c expression and determines both hepatic lipid content and overall insulin sensitivity. J Clin Invest 112: 935-944.

Matsushima R, Harada N, Webster NJ, Tsutsumi YM, Nakaya Y. 2006. Effect of TRB3 on insulin and nutrientstimulated hepatic p70 S6 kinase activity. J Biol Chem 281: 29719-29729.

McClain DA. 2002. Hexosamines as mediators of nutrient sensing and regulation in diabetes. J Diabetes Complications 16: 72-80.

McClain DA, Lubas WA, Cooksey RC, Hazel M, Parker GJ, Love DC, Hanover JA. 2002. Altered glycan-dependent signaling induces insulin resistance and hyperleptinemia. Proc Natl Acad Sci 99: 10695-10699.

Miele C, Riboulet A, Maitan MA, Oriente F, Romano C, Formisano P, Giudicelli J, Beguinot F, Van Obberghen E. 2003. Human glycated albumin affects glucose metabolism in L6 skeletal muscle cells by impairing insulin-induced insulin receptor substrate (IRS) signaling through a protein kinase $\mathrm{C} \alpha$-mediated mechanism. $J$ Biol Chem 278: 47376-47387.

Miki H, Yamauchi T, Suzuki R, Komeda K, Tsuchida A, Kubota N, Terauchi Y, Kamon J, Kaburagi Y, Matsui J, et al. 2001. Essential role of insulin receptor substrate 1 (IRS-1) and IRS-2 in adipocyte differentiation. Mol Cell Biol 21: 2521-2532.

Millward TA, Zolnierowicz S, Hemmings BA. 1999. Regulation of protein kinase cascades by protein phosphatase 2A. Trends Biochem Sci 24: 186-191. 
J. Boucher et al.

Mosthaf L, Grako K, Dull TJ, Coussens L, Ullrich A, McClain DA. 1990. Functionally distinct insulin receptors generated by tissue-specific alternative splicing. EMBO J 9: 2409-2413.

Motti ML, De MC, Califano D, Fusco A, Viglietto G. 2004 Akt-dependent T198 phosphorylation of cyclin-dependent kinase inhibitor p27kip1 in breast cancer. Cell Cycle 3: $1074-1080$

Myers MG Jr, Backer JM, Sun XJ, Shoelson S, Hu P, Schlessinger J, Yoakim M, Schaffhausen B, White MF. 1992 IRS-1 activates phosphatidylinositol $3^{\prime}$-kinase by associating with src homology 2 domains of p85. Proc Nat Acad Sci 89: 10350-10354.

Nef S, Verma-Kurvari S, Merenmies J, Vassalli JD, Efstratiadis A, Accili D, Parada LF. 2003. Testis determination requires insulin receptor family function in mice. Nature 426: 291-295.

Ni YG, Wang N, Cao DJ, Sachan N, Morris DJ, Gerard RD, Kuro O, Rothermel BA, Hill JA. 2007. FoxO cription factors activate Akt and attenuate insulin signaling in heart by inhibiting protein phosphatases. Proc Natl Acad Sci 104: 20517-20522.

Oh WJ, Jacinto E. 2011. mTOR complex 2 signaling and functions. Cell Cycle 10: 2305-2316.

Osborn O, Olefsky JM. 2012. The cellular and signaling networks linking the immune system and metabolism in disease. Nat Med 18: 363-374.

Ozcan U, Cao Q, Yilmaz E, Lee AH, Iwakoshi NN, Ozdelen E, Tuncman G, Gorgun C, Glimcher LH, Hotamisligil GS. 2004. Endoplasmic reticulum stress links obesity, insulin action, and type 2 diabetes. Science 306: 457-461.

Ozcan L, Ergin AS, Lu A, Chung J, Sarkar S, Nie D, Myers MG Jr, Ozcan U. 2009. Endoplasmic reticulum stress plays a central role in development of leptin resistance. Cell Metab 9: 35-51.

Ozes ON, Akca H, Mayo LD, Gustin JA, Maehama T, Dixon JE, Donner DB. 2001. A phosphatidylinositol 3-kinase/ Akt/mTOR pathway mediates and PTEN antagonizes tumor necrosis factor inhibition of insulin signaling through insulin receptor substrate-1. Proc Natl Acad Sci 98: 4640-4645.

Pal A, Barber TM, Van de Bunt M, Rudge SA, Zhang Q, Lachlan KL, Cooper NS, Linden H, Levy JC, Wakelam MJ, et al. 2012. PTEN mutations as a cause of constitutive insulin sensitivity and obesity. N Engl J Med 367: 1002 1011.

Pandini G, Vigneri R, Costantino A, Frasca F, Ippolito A, Fujita-Yamaguchi Y, Siddle K, Goldfine ID, Belfiore A. 1999. Insulin and insulin-like growth factor-I (IGF-I) receptor overexpression in breast cancers leads to insulin/IGF-I hybrid receptor overexpression: Evidence for a second mechanism of IGF-I signaling. Clin Cancer Res 5: 1935-1944.

Park SW, Zhou Y, Lee J, Lu A, Sun C, Chung J, Ueki K, Ozcan J. 2010. The regulatory subunits of PI3K, p85 $\alpha$ and $p 85 \beta$, interact with XBP-1 and increase its nuclear translocation. Nat Med 16: 429-437.

Patti ME, Virkamaki A, Landaker EJ, Kahn CR, Yki-Jarvinen H. 1999. Activation of the hexosamine pathway by glucosamine in vivo induces insulin resistance of early postreceptor insulin signaling events in skeletal muscle. Diabetes 48: 1562-1571.
Pearce LR, Komander D, Alessi DR. 2010. The nuts and bolts of AGC protein kinases. Nat Rev Mol Cell Biol 11: 9-22.

Peng G, Li L, Liu Y, Pu J, Zhang S, Yu J, Zhao J, Liu P. 2011. Oleate blocks palmitate-induced abnormal lipid distribution, endoplasmic reticulum expansion and stress, and insulin resistance in skeletal muscle. Endocrinology 152: 2206-2218.

Powell DJ, Hajduch E, Kular G, Hundal HS. 2003. Ceramide disables 3-phosphoinositide binding to the pleckstrin homology domain of protein kinase B (PKB)/Akt by a PKCל-dependent mechanism. Mol Cell Biol 23: 77947808.

Powell DJ, Turban S, Gray A, Hajduch E, Hundal HS. 2004. Intracellular ceramide synthesis and protein kinase $\mathrm{C} \zeta$ activation play an essential role in palmitate-induced insulin resistance in rat L6 skeletal muscle cells. Biochem J 382: 619-629.

Prudente S, Hribal ML, Flex E, Turchi F, Morini E, De Cosmo S, Bacci S, Tassi V, Cardellini M, Lauro R, et al. 2005. The functional Q84R polymorphism of mammalian Tribbles homolog TRB3 is associated with insulin resistance and related cardiovascular risk in Caucasians from Italy. Diabetes 54: 2807-2811.

Prudente S, Scarpelli D, Chandalia M, Zhang YY, Morini E, Del Guerra S, Perticone F, Li R, Powers C, Andreozzi F, et al. 2009. The TRIB3 Q84R polymorphism and risk of early-onset type 2 diabetes. J Clin Endocrinol Metab 94: 190-196.

Qi L, Heredia JE, Altarejos JY, Screaton R, Goebel N, Niessen S, Macleod IX, Liew cW, Kulkarni RN, Bain J, et al. 2006. TRB3 links the E3 ubiquitin ligase COP1 to lipid metabolism. Science 312: 1763-1766.

Ravichandran LV, Esposito DL, Chen J, Quon MJ. 2001. Protein kinase $\mathrm{C}-\zeta$ phosphorylates insulin receptor substrate- 1 and impairs its ability to activate phosphatidylinositol 3-kinase in response to insulin. J Biol Chem 276: 3543-3549.

Reyna SM, Ghosh S, Tantiwong P, Meka CS, Eagan P, Jenkinson CP, Cersosimo E, DeFronzo RA, Coletta DK, Sriwijitkamol A, et al. 2008. Elevated toll-like receptor 4 expression and signaling in muscle from insulin-resistant subjects. Diabetes 57: 2595-2602.

Riboulet-Chavey A, Pierron A, Durand I, Murdaca J, Giudicelli J, Van OE. 2006. Methylglyoxal impairs the insulin signaling pathways independently of the formation of intracellular reactive oxygen species. Diabetes 55: 12891299.

Rosen P, Nawroth PP, King G, Moller W, Tritschler HJ, Packer L. 2001. The role of oxidative stress in the onset and progression of diabetes and its complications: A summary of a Congress Series sponsored by UNESCOMCBN, the American Diabetes Association and the German Diabetes Society. Diabetes Metab Res Rev 17: 189212.

Roth RA, Beaudoin J. 1987. Phosphorylation of purified insulin receptor by cAMP kinase. Diabetes 36: 123-126.

Rotter V, Nagaev I, Smith U. 2003. Interleukin-6 (IL-6) induces insulin resistance in 3T3-L1 adipocytes and is, like IL-8 and tumor necrosis factor- $\alpha$, overexpressed in human fat cells from insulin-resistant subjects. J Biol Chem 278: $45777-45784$. 
Rudich A, Tirosh A, Potashnik R, Hemi R, Kanety H, Bashan N. 1998. Prolonged oxidative stress impairs insulin-induced GLUT4 translocation in 3T3-L1 adipocytes. Diabetes 47: 1562-1569.

Rui L, Yuan M, Frantz D, Shoelson S, White MF. 2002. SOCS-1 and SOCS-3 block insulin signaling by ubiquitin-mediated degradation of IRS1 and IRS2. J Biol Chem 277: 42394-42398.

Sachithanandan N, Fam BC, Fynch S, Dzamko N, Watt MJ, Wormald S, Honeyman J, Galic S, Proietto J, Andrikopoulos S, et al. 2010. Liver-specific suppressor of cytokine signaling-3 deletion in mice enhances hepatic insulin sensitivity and lipogenesis resulting in fatty liver and obesity. Hepatology 52: 1632-1642.

Sajan MP, Rivas J, Li P, Standaert ML, Farese RV. 2006. Repletion of atypical protein kinase C following RNA interference-mediated depletion restores insulin-stimulated glucose transport. J Biol Chem 281: 17466-17473.

Sakamoto K, Holman GD. 2008. Emerging role for AS160/ TBC1D4 and TBC1D1 in the regulation of GLUT4 traffic. Am J Physiol Endocrinol Metab 295: E29-E37.

Samuel VT, Liu ZX, Wang A, Beddow SA, Geisler JG, Kahn M, Zhang XM, Monia BP, Bhanot S, Shulman GI. 2007. Inhibition of protein kinase $\mathrm{C} \varepsilon$ prevents hepatic insulin resistance in nonalcoholic fatty liver disease. J Clin Invest 117: $739-745$.

Samuel VT, Petersen KF, Shulman GI. 2010. Lipid-induced insulin resistance: Unravelling the mechanism. Lancet 375: $2267-2277$.

Sano H, Kane S, Sano E, Miinea CP, Asara JM, Lane WS, Garner CW, Lienhard GE. 2003. Insulin-stimulated phosphorylation of a Rab GTPase-activating protein regulates GLUT4 translocation. J Biol Chem 278: 1459914602.

Sarbassov DD, Guertin DA, Ali SM, Sabatini DM. 2005. Phosphorylation and regulation of Akt/PKB by the rictor-mTOR complex. Science 307: 1098-1101.

Schenk S, Saberi M, Olefsky JM. 2008. Insulin sensitivity: Modulation by nutrients and inflammation. J Clin Invest 118: 2992-3002.

Schultze SM, Jensen J, Hemmings BA, Tschopp O, Niessen M. 2011. Promiscuous affairs of $\mathrm{PKB} / \mathrm{AKT}$ isoforms in metabolism. Arch Physiol Biochem 117: 70-77.

Sciacchitano S, Taylor SI. 1997. Cloning, tissue expression, and chromosomal localization of the mouse IRS-3 gene. Endocrinology 138: 4931-4940.

Shah OJ, Wang Z, Hunter T. 2004. Inappropriate activation of the TSC/Rheb/mTOR/S6K cassette induces IRS1/2 depletion, insulin resistance, and cell survival deficiencies. Curr Biol 14: 1650-1656.

Shao J, Catalano PM, Yamashita H, Ruyter I, Smith S, Youngren J, Friedman JE. 2000. Decreased insulin receptor tyrosine kinase activity and plasma cell membrane glycoprotein-1 overexpression in skeletal muscle from obese women with gestational diabetes mellitus (GDM): Evidence for increased serine/threonine phosphorylation in pregnancy and GDM. Diabetes 49: 603610.

Shaw LM. 2011. The insulin receptor substrate (IRS) proteins: At the intersection of metabolism and cancer. Cell Cycle 10: 1750-1756.
Shi H, Kokoeva MV, Inouye K, Tzameli I, Yin H, Flier JS. 2006. TLR4 links innate immunity and fatty acid-induced insulin resistance. J Clin Invest 116: 3015-3025.

Shiura H, Miyoshi N, Konishi A, Wakisaka-Saito N, Suzuki K, Muguruma R, Kohda T, Wakana S, Yokoyama M, Ishino F, et al. 2005. Meg1/Grb10 overexpression causes postnatal growth retardation and insulin resistance via negative modulation of the IGF1R and IR cascades. Biochem Biophys Res Commun 329: 909-916.

Siddle K. 2012. Molecular basis of signaling specificity of insulin and IGF receptors: Neglected corners and recent advances. Front Endocrinol (Lausanne) 3: 34.

Sinha S, Perdomo G, Brown NF, O’Doherty RM. 2004. Fatty acid-induced insulin resistance in L6 myotubes is prevented by inhibition of activation and nuclear localization of nuclear factor к B. J Biol Chem 279: 41294-41301.

Sleeman MW, Wortley KE, Lai KM, Gowen LC, Kintner J, Kline WO, Garcia K, Stitt TN, Yancopoulos GD, Wiegand SJ, et al. 2005. Absence of the lipid phosphatase SHIP2 confers resistance to dietary obesity. Nat Med 11: 199-205.

Smith FM, Holt LJ, Garfield AS, Charalambous M, Koumanov F, Perry M, Bazzani R, Sheardown SA, Hegarty BD, Lyons RJ, et al. 2007. Mice with a disruption of the imprinted Grb10 gene exhibit altered body composition, glucose homeostasis, and insulin signaling during postnatal life. Mol Cell Biol 27: 5871-5886.

Sopasakis VR, Liu P, Suzuki R, Kondo T, Winnay J, Tran TT, Asano T, Smyth G, Sajan MP, Farese RV, et al. 2010. Specific roles of the $\mathrm{p} 110 \alpha$ isoform of phosphatidylinsositol 3-kinase in hepatic insulin signaling and metabolic regulation. Cell Metab 11: 220-230.

Stadtmauer LA, Rosen OM. 1986. Increasing the cAMP content of IM-9 cells alters the phosphorylation state and protein kinase activity of the insulin receptor. J Biol Chem 261: 3402-3407.

Steppan CM, Wang J, Whiteman EL, Birnbaum MJ, Lazar MA. 2005. Activation of SOCS-3 by resistin. Mol Cell Biol 25: $1569-1575$.

Stiles B, Wang Y, Stahl A, Bassilian S, Lee WP, Kim YJ, Sherwin R, Devaskar S, Lesche R, Magnuson MA, et al. 2004. Liver-specific deletion of negative regulator Pten results in fatty liver and insulin hypersensitivity [corrected]. Proc Natl Acad Sci 101: 2082-2087.

Sun XJ, Rothenberg PL, Kahn CR, Backer JM, Araki E, Wilden PA, Cahill DA, Goldstein BJ, White MF. 1991 Structure of the insulin receptor substrate IRS-1 defines a unique signal duction protein. Nature 352: 73-77.

Sun XJ, Crimmins DL, Myers MR Jr, Miralpeix M, White MF. 1993. Pleiotropic insulin signals are engaged by multisite phosphorylation of IRS-1. Mol Cell Biol 13: 74187428.

Sun XJ, Wang LM, Zhang Y, Yenush L, Myers MG Jr, Glasheen E, Lane WS, Pierce JH, White MF. 1995. Role of IRS-2 in insulin and cytokine signalling. Nature 377: $173-177$.

Sun K, Kusminski CM, Scherer PE. 2011. Adipose tissue remodeling and obesity. J Clin Invest 121: 2094-2101.

Suwa A, Kurama T, Shimokawa T. 2010. SHIP2 and its involvement in various diseases. Expert Opin Ther Targets 14: $727-737$. 
J. Boucher et al.

Tan K, Kimber WA, Luan J, Soos MA, Semple RK, Wareham NJ, O’Rahilly S, Barroso I. 2007. Analysis of genetic variation in Akt $2 / \mathrm{PKB}-\beta$ in severe insulin resistance, lipodystrophy, type 2 diabetes, and related metabolic phenotypes. Diabetes 56: 714-719.

Taniguchi CM, Emanuelli B, Kahn CR. 2006a. Critical nodes in signalling pathways: Insights into insulin action. Nat Rev Mol Cell Biol 7: 85-96.

Taniguchi CM, Tran TT, Kondo T, Luo J, Ueki K, Cantley LC, Kahn CR. 2006b. Phosphoinositide 3-kinase regulatory subunit $\mathrm{p} 85 \alpha$ suppresses insulin action via positive regulation of PTEN. Proc Natl Acad Sci 103: 12093-12097.

Taniguchi CM, Winnay J, Kondo T, Bronson RT, Guimaraes AR, Aleman JO, Luo J, Stephanopoulos G, Weissleder R, Cantley LC, et al. 2010. The phosphoinositide 3-kinase regulatory subunit $\mathrm{p} 85 \alpha$ can exert tumor suppressor properties through negative regulation of growth factor signaling. Cancer Res 70: 5305-5315.

Taylor SI, Accili D, Cama A, Kadowaki H, Kadowaki T, Imano E, Sierra ML. 1991. Mutations in the insulin receptor gene in patients with genetic syndromes of insulin resistance. Adv Exp Med Biol 293: 197-213.

Taylor EB, An D, Kramer HF, Yu H, Fujiii NL, Roeckl KS, Bowles N, Hirshman MF, Xie J, Feener EP, et al. 2008. Discovery of TBC1D1 as an insulin-, AICAR-, and contraction-stimulated signaling nexus in mouse skeletal muscle. J Biol Chem 283: 9787-9796.

Terauchi Y, Tsuji Y, Satoh S, Minoura H, Murakami K, Okuno A, Inukai K, Asano T, Kaburagi Y, Ueki K, et al. 1999. Increased insulin sensitivity and hypoglycaemia in mice lacking the p85 $\alpha$ subunit of phosphoinositide 3kinase. Nat Genet 21: 230-235.

Teruel T, Hernandez R, Lorenzo M. 2001. Ceramide mediates insulin resistance by tumor necrosis factor- $\alpha$ in brown adipocytes by maintaining Akt in an inactive dephosphorylated state. Diabetes 50: 2563-2571.

Tseng YH, Butte AJ, Kokkotou E, Yechoor VK, Taniguchi CM, Kriauciunas KM, Cypess AM, Niinobe M, Yoshikawa K, Patti ME, et al. 2005. Prediction of preadipocyte differentiation by gene expression reveals role of insulin receptor substrates and necdin. Nat Cell Biol 7: 601-611.

Turban S, Hajduch E. 2011. Protein kinase C isoforms: Mediators of reactive lipid metabolites in the development of insulin resistance. Growth Regul 585: 269-274.

Tzivion G, Dobson M, Ramakrishnan G. 2011. FoxO cription factors; Regulation by AKT and 14-3-3 proteins. Biochim Biophys Acta 1813: 1938-1945.

Ueki K, Yballe CM, Brachmann SM, Vicent D, Watt JM, Kahn CR, Cantley LC. 2002. Increased insulin sensitivity in mice lacking $\mathrm{p} 85 \beta$ subunit of phosphoinositide 3-kinase. Proc Natl Acad Sci 99: 419-424.

Ueki K, Kondo T, Kahn CR. 2004a. Suppressor of cytokine signaling 1 (SOCS-1) and SOCS-3 cause insulin resistance through inhibition of tyrosine phosphorylation of insulin receptor substrate proteins by discrete mechanisms. Mol Cell Biol 24: 5434-5446.

Ueki K, Kondo T, Tseng YH, Kahn CR. 2004b. Central role of suppressors of cytokine signaling proteins in hepatic steatosis, insulin resistance, and the metabolic syndrome in the mouse. Proc Natl Acad Sci 101: 10422-10427.

Um SH, Frigerio F, Watanabe M, Picard F, Joaquin M, Sticker M, Fumagalli S, Allegrini PR, Kozma SC, Auwerx
J, et al. 2004. Absence of S6K1 protects against age- and diet-induced obesity while enhancing insulin sensitivity. Nature 431: 200-205.

Vadas O, Burke JE, Zhang X, Berndt A, Williams RL. 2011. Structural basis for activation and inhibition of class I phosphoinositide 3-kinases. Sci Signal 4: re2.

van Dam RM, Hoebee B, Seidell JC, Schaap MM, Blaak EE, Feskens EJ. 2004. The insulin receptor substrate-1 Gly972Arg polymorphism is not associated with type 2 diabetes mellitus in two population-based studies. Diabet Med 21: $752-758$.

Versteyhe S, Blanquart C, Hampe C, Mahmood S, Christeff N, De MP, Gray SG, Issad T. 2010. Insulin receptor substrates-5 and -6 are poor substrates for the insulin receptor. Mol Med Report 3: 189-193.

Voliovitch H, Schindler DG, Hadari YR, Taylor SI, Accili D, Zick Y. 1995. Tyrosine phosphorylation of insulin receptor substrate- 1 in vivo depends upon the presence of its pleckstrin homology region. J Biol Chem 270: 1808318087.

Wang L, Balas B, Christ-Roberts CY, Kim RY, Ramos FJ, Kikani CK, Li C, Deng C, Reyna S, Musi N, et al. 2007. Peripheral disruption of the Grb10 gene enhances insulin signaling and sensitivity in vivo. Mol Cell Biol 27: 64976505.

Weisberg SP, Hunter D, Huber R, Lemieux J, Slaymaker S, Vaddi K, Charo I, Leibel RL, Ferrante AW Jr. 2006. CCR2 modulates inflammatory and metabolic effects of highfat feeding. J Clin Invest 116: 115-124.

West IC. 2000. Radicals and oxidative stress in diabetes Diabet Med 17: 171-180.

Westwick JK, Bielawska AE, Dbaibo G, Hannun YA, Brenner DA. 1995. Ceramide activates the stress-activated protein kinases. J Biol Chem 270: 22689-22692.

White MF. 2006. Regulating insulin signaling and $\beta$-cell function through IRS proteins. Can J Physiol Pharmacol 84: 725-737.

Wijesekara N, Konrad D, Eweida M, Jefferies C, Liadis N, Giacca A, Crackower M, Suzuki A, Mak TW, Kahn CR, et al. 2005. Muscle-specific Pten deletion protects against insulin resistance and diabetes. Mol Cell Biol 25: 11351145.

Winnay JN, Boucher J, Mori MA, Ueki K, Kahn CR. 2010. A regulatory subunit of phosphoinositide 3-kinase increases the nuclear accumulation of X-box-binding protein-1 to modulate the unfolded protein response. Nat Med 16: $438-445$.

Withers DJ, Gutierrez JS, Towery H, Burks DJ, Ren JM, Previs S, Zhang Y, Bernal D, Pons S, Shulman Gi, et al. 1998. Disruption of IRS-2 causes type 2 diabetes in mice. Nature 391: 900-904.

Wong JT, Kim PT, Peacock JW, Yau TY, Mui AL, Chung SW, Sossi V, Doudet D, Green D, Ruth TJ, et al. 2007. Pten (phosphatase and tensin homologue gene) haploinsufficiency promotes insulin hypersensitivity. Diabetologia 50: $395-403$

Wong RH, Chang I, Hudak CS, Hyun S, Kwan HY, Sul HS. 2009. A role of DNA-PK for the metabolic gene regulation in response to insulin. Cell 136: 1056-1072.

Xia P, Inoguchi T, Kern TS, Engerman RL, Oates PJ, King GL. 1994. Characterization of the mechanism for the 
chronic activation of diacylglycerol-protein kinase C pathway in diabetes and hypergalactosemia. Diabetes 43: $1122-1129$.

Yamaguchi H, Wang HG. 2001. The protein kinase PKB/Akt regulates cell survival and apoptosis by inhibiting Bax conformational change. Oncogene 20: 7779-7786.

Yi Z, Langlais P, De Filippis EA, Luo M, Flynn CR, Schroeder S, Weintraub ST, Mapes R, Mandarino LJ. 2007. Global assessment of regulation of phosphorylation of insulin receptor substrate-1 by insulin in vivo in human muscle. Diabetes 56: 1508-1516.

Yu J, Zhang Y, McIlroy J, Rordorf-Nikolic T, Orr GA, Backer JM. 1998. Regulation of the p85/p110 phosphatidylinositol 3'-kinase: Stabilization and inhibition of the p110 $\alpha$ catalytic subunit by the $\mathrm{p} 85$ regulatory subunit. Mol Cell Biol 18: 1379-1387.

Yu C, Chen Y, Zong H, Wang Y, Bergeron R, Kim JK, Cline GW, Cushman SW, Cooney GJ, Atcheson B, et al. 2002. Mechanism by which fatty acids inhibit insulin activation of IRS-1 associated phosphatidylinositol 3-kinase activity in muscle. J Biol Chem 277: 50230-50236.

Yu Q, Gao F, Ma XL. 2011a. Insulin says NO to cardiovascular disease. Cardiovasc Res 89: 516-524.

Yu Y, Yoon SO, Poulogiannis G, Yang Q, Ma XM, Villen J, Kubica N, Hoffman GR, Cantley LC, Gygi SP, et al. 2011b. Phosphoproteomic analysis identifies Grb10 as an mTORC1 substrate that negatively regulates insulin signaling. Science 332: 1322-1326.

Yuan M, Konstantopoulos N, Lee J, Hansen L, Li ZW, Karin M, Shoelson SE. 2001. Reversal of obesity- and diet-in- duced insulin resistance with salicylates or targeted disruption of Ikk $\beta$. Science 293: 1673-1677.

Zhang D, Liu ZX, Choi CS, Tian L, Kibbey R, Dong J, Cline GW, Wood PA, Shulman GI. 2007. Mitochondrial dysfunction due to long-chain Acyl-CoA dehydrogenase deficiency causes hepatic steatosis and hepatic insulin resistance. Proc Natl Acad Sci 104: 17075-17080.

Zhang J, Gao Z, Yin J, Quon MJ, Ye J. 2008a. S6K directly phosphorylates IRS-1 on Ser-270 to promote insulin resistance in response to TNF- $\alpha$ signaling through IKK2. J Biol Chem 283: 35375-35382.

Zhang X, Zhang G, Zhang H, Karin M, Bai H, Cai D. 2008b. Hypothalamic IKK- $\beta$ /NF-кB and ER stress link overnutrition to energy imbalance and obesity. Cell 135: 61-73.

Zhang X, Vadas O, Perisic O, Anderson KE, Clark J, Hawkins PT, Stephens LR, Williams RL. 2011. Structure of lipid kinase $\mathrm{p} 110 \beta / \mathrm{p} 85 \beta$ elucidates an unusual SH2-domainmediated inhibitory mechanism. Mol Cell 41: 567-578.

Zhou Q, Dolan PL, Dohm GL. 1999. Dephosphorylation increases insulin-stimulated receptor kinase activity in skeletal muscle of obese Zucker rats. Mol Cell Biochem 194: 209-216.

Zhou BP, Liao Y, Xia W, Zou Y, Spohn B, Hung MC. 2001. HER-2/neu induces p53 ubiquitination via Akt-mediated MDM2 phosphorylation. Nat Cell Biol 3: 973-982.

Zisman A, Peroni OD, Abel ED, Michael MD, Mauvais-Jarvis F, Lowell BB, Wojtaszewski JF, Hirshman MF, Virkamaki A, Goodyear LJ, et al. 2000. Targeted disruption of the glucose transporter 4 selectively in muscle causes insulin resistance and glucose intolerance. Nat Med 6: 924-928. 


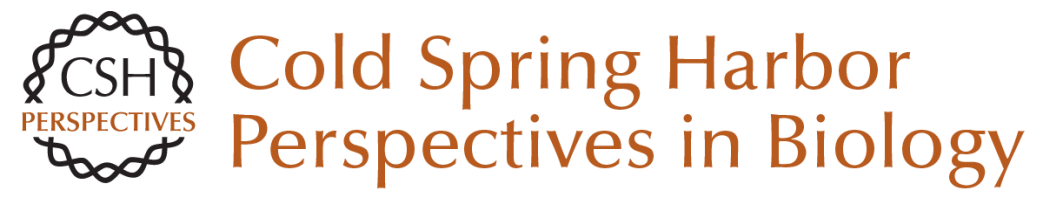

\section{Insulin Receptor Signaling in Normal and Insulin-Resistant States}

Jérémie Boucher, André Kleinridders and C. Ronald Kahn

Cold Spring Harb Perspect Biol 2014; doi: 10.1101/cshperspect.a009191

Subject Collection Signaling by Receptor Tyrosine Kinases

CSF-1 Receptor Signaling in Myeloid Cells

E. Richard Stanley and Violeta Chitu

The EGFR Family: Not So Prototypical Receptor Tyrosine Kinases

Mark A. Lemmon, Joseph Schlessinger and Kathryn M. Ferguson

Tie2 and Eph Receptor Tyrosine Kinase Activation and Signaling

William A. Barton, Annamarie C. Dalton, Tom C.M. Seegar, et al.

The Spatiotemporal Organization of ErbB

Receptors: Insights from Microscopy

Christopher C. Valley, Keith A. Lidke and Diane S. Lidke

Insulin Receptor Signaling in Normal and Insulin-Resistant States

Jérémie Boucher, André Kleinridders and C. Ronald Kahn

Central Role of RET in Thyroid Cancer Massimo Santoro and Francesca Carlomagno

Receptor Tyrosine Kinase-Mediated Angiogenesis Michael Jeltsch, Veli-Matti Leppänen, Pipsa Saharinen, et al.

Biology of the TAM Receptors Greg Lemke
The Genesis of Tyrosine Phosphorylation Tony Hunter

Structure-Function Relationships of ErbB RTKs in the Plasma Membrane of Living Cells

Donna J. Arndt-Jovin, Michelle G. Botelho and Thomas M. Jovin

Receptor Tyrosine Kinases: Legacy of the First

Two Decades Joseph Schlessinger

The Role of Ryk and Ror Receptor Tyrosine Kinases in Wnt Signal Transduction Jennifer Green, Roel Nusse and Renée van Amerongen

Regulation of Receptor Tyrosine Kinase Ligand Processing Colin Adrain and Matthew Freeman

Molecular Mechanisms of SH2- and PTB-Domain-Containing Proteins in Receptor Tyrosine Kinase Signaling Melany J. Wagner, Melissa M. Stacey, Bernard A. Liu, et al.

Eph Receptor Signaling and Ephrins Erika M. Lisabeth, Giulia Falivelli and Elena B. Pasquale

Effects of Membrane Trafficking on Signaling by

Receptor Tyrosine Kinases Marta Miaczynska

For additional articles in this collection, see http://cshperspectives.cshlp.org/cgi/collection/

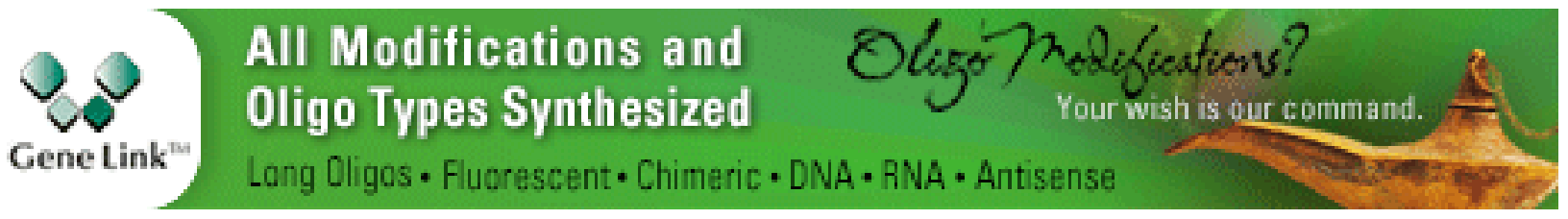


For additional articles in this collection, see http://cshperspectives.cshlp.org/cgi/collection/

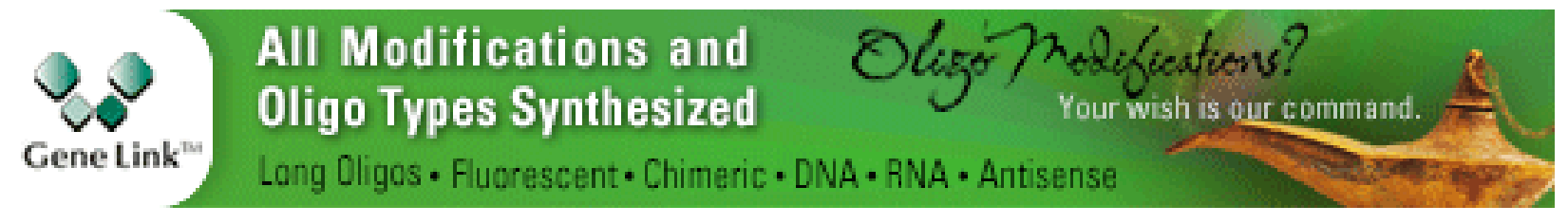

Copyright @ 2014 Cold Spring Harbor Laboratory Press; all rights reserved 